\title{
Real Activities Manipulation by Bidders prior to Mergers and Acquisitions
}

\begin{tabular}{|r|l|}
\hline Journal: & Review of Accounting and Finance \\
\hline Manuscript ID & RAF-12-2014-0132.R6 \\
\hline Manuscript Type: & Research Paper \\
\hline Keywords: & $\begin{array}{l}\text { Mergers and Acquisitions, Discretionary Accruals, Real Earnings } \\
\text { Management }\end{array}$ \\
\hline \multicolumn{2}{|l}{} \\
\hline
\end{tabular}

\author{
SCHOLARONE $^{\text {"x }}$ \\ Manuscripts
}




\title{
Real Activities Manipulation by Bidders prior to Mergers and Acquisitions
}

\begin{abstract}
This study examines the ability of investors to process signs of real activities manipulations at bidder firms in the quarters leading to the announcement of a merger. It further provides a supplementary explanation for the post-merger underperformance puzzle. Examining a sample of cash-only, stock-swap, and mixed mergers completed between 1980 and 2011, we find that bidder firms increase the use of real activities manipulation in the quarters leading up to the merger announcements. Using the average abnormal stock return method, we show that the short-term positive effect of real activities manipulation on share prices is stronger than accrualbased earnings management. While bidders are able to escape investors' scrutiny in the short run, it is not the case in the long run. We find that bidders' long run stock performance-measured by matched buy-and-hold stock returns - is inversely related to their pre-announcement level of earnings management. We contribute to the literature on earnings management by considering how real activities manipulations affect stock prices in mergers and acquisitions.

JEL classification: G14, G34, M41

Keywords: Mergers and Acquisitions; Discretionary Accruals; Real Earnings Management
\end{abstract}




\section{Real Activities Manipulation by Bidders prior to Mergers and Acquisitions}

\section{Introduction}

Past studies on acquiring firms manipulating earnings prior to a merger or acquisition (M\&A) include Erickson and Wang (1999), Louis (2004), Baik, Kang and Morton (2007), Bostsari and Meeks (2008), and Gong, Louis and Sun (2008). They find that earnings management by bidder (acquiring) firms using discretionary accruals is prevalent in stock bids as managers attempt to boost their stock prices. For example, Louis (2004) focuses on accrualbased earnings management and finds that bidder firms that engaged in positive accrual earnings management benefited from stock price increases during the merger announcement. Gong, Louis, and Sun (2008) find that post-repurchase performance is driven by pre-repurchase earnings management. While these past studies document the impact of accrual earnings manipulation on stock returns during M\&A, they do not take account of real activities manipulations. Recently, an increasing number of firms are engaging in real activities manipulation as well as accrual earnings management and, high accruals are not always indicative of earnings management since they could be related to firm growth.

We hypothesize that bidders not only manipulate discretionary accruals prior to M\&As, but they also engage in real activities manipulations. Firms are inclined to use the latter as they are harder to detect by outsiders. Louis (2004) provides examples that show even sophisticated investors are unable to detect real earnings management. He also finds that the reversal effects of the pre-merger earnings management are not fully anticipated by financial analysts immediately following a merger announcement.

Besides, a survey of CFOs by Dichev, Graham, Harvey and Rajgopal (2013) shows that nondiscretionary factors drive about 50\% of earnings quality. Moreover, Zang (2012) argues that 
there is a greater likelihood of firms to engage in real activities manipulation, especially when firms are constrained in their use of accrual-based earnings management due to heightened scrutiny or overuse in prior years.

In view of the above, it is important to examine the effects of both real activities manipulation and accrual-based earnings management. We examine whether bidder firms manipulate earnings prior to M\&As using both forms of earnings management. More specifically, we investigate whether bidders increase the use of real earnings management prior to M\&As involving stock swaps. We consider U.S. domestic stock swap deals from 1980 to 2011. We compare the changes in earnings management from pre- to post-M\&A. In multiple regression models, we regress various measures of earnings management on several dummy variables representing alternative time periods surrounding the M\&A announcements.

We find strong evidence that bidders increase their use of real activities manipulation in the quarters preceding a stock swap announcement. We find that the market reaction over the three days surrounding a merger announcement is positively linked to the bidder's use of real activities manipulation. In the long run, though, the relationship between real activities manipulation and bidders' stock performance turns negative. Our findings suggest two things: the first is that manipulating earnings can yield short-term benefits to bidder firms in stock-forstock mergers. The second is that investors take time to recognize and respond to the intricacies of earnings management at bidder firms.

The remainder of the paper is organized as follows. We perform a literature review in Section 2. We formulate our hypotheses in Section 3. Data and the sample selection procedure 
are presented in Section 4. Section 5 discusses the methodology. We present and discuss our findings in Section 6, and conclude the paper in Section 7.

\section{Literature Review}

According to the extant literature, the relationship between accruals and stock returns is mixed. Sloan (1996) finds that future stock returns are negatively linked to accruals. Firms with high accruals experience a subsequent decline in cash flows. Abnormally high accruals are consistent with a firm manipulating earnings to show a healthy bottom line. However, other studies have shown high accruals are not always indicative of earnings management. Growing businesses will accrue expenses while they use scarce cash to finance growth. Once the growth potential is reached, they will repay the accrued expenses. Along these lines, Subramanyam (1996) documents a positive relationship between abnormal accruals and stock returns, indicating that high accruals signal that the business prospects and growth potential are strong.

Several studies also find a positive relationship between accruals and stock returns. Demski (1998) argues that high accruals signal managers' expertise and greater future returns. Louis and Robinson (2005) assert that a higher level of accruals prior to a stock split is a signal of managerial optimism, which is further reinforced by the stock split. Xu and Lacina (2009) claim that lower accrual firms tend to experience lower future returns as opposed to higher accrual firms since they are perceived as less risky firms.

Louis (2004) documents a significantly negative correlation between the abnormal accruals and the abnormal returns of acquiring firms that engage in stock swaps. He further finds that the post-merger underperformance of bidder firms is partly attributable to the reversal of the price effects of earnings management. Erickson and Wang (1999) find that acquirers manage 
earnings upwards before engaging in a merger agreement. Botsari and Meeks (2008) similarly find evidence consistent with earnings management ahead of share-financed bids. Baik, Kang and Morton (2007) find that firms are more likely to report income-increasing abnormal accruals prior to the acquisitions of privately held targets when shares are used as the M\&A currency. Gong, Louis, and Sun (2008) find that post-repurchase performance is driven by pre-repurchase earnings management.

We build on the existing literature by testing whether real activities manipulation, in addition to accrual-based earnings management, explains the underperformance puzzle of the acquiring firms in M\&As. Since a growing number of firms are involved in real activities manipulation, it is important to include this form of earnings management within the analysis (Dichev, Graham, Harvey and Rajgopal, 2013).

\section{Hypotheses}

Bidders in stock swap deals have an incentive to inflate earnings figures prior to an M\&A. The theory is that the higher earnings figures will translate into higher stock prices, thus reducing the number of shares to be issued in stock-financed deals. We test whether there is an increase in earnings management in the quarters leading to the M\&A announcement.

H1: Earnings management is higher during the pre-M\&A announcement for bidder firms compared to post-announcement periods.

In deals that are financed with stock and cash, and where the latter is backed by debt (Bharadwaj and Shivdasani, 2003; Harford, Klasa, and Walcott, 2009), the presence of lending 
parties inhibits the bidder's ability to manipulate earnings. ${ }^{1}$ Since its interest is also at stake, a creditor will verify that earnings manipulation is not driving the bidder's reported profits. Consequently, there will be a lower incidence of earnings management in bids that are partly funded with debt.

H2: $\quad$ Earnings management by bidders pre-M\&A is lower in cash-financed deals.

We further hypothesize that the larger is the deal size relative to the bidder, the more incentivized is the bidder to manipulate earnings. Moreover, the larger is the bidder's firm size, the more intricate is the organization structure. Thus, we should observe a higher incidence of earnings management both in large deals and amongst large bidders.

H3: $\quad$ Earnings management correlates positively with bidder's firm size.

It is likely that the effects of earnings management on shareholders' wealth are more pronounced under real activities manipulation than accrual-based earnings manipulation. Besides impeding the future revenue earnings capability of the business assets, real activities manipulations significantly impair the value of the firm's assets. Consider a company's decision to postpone refurbishment of its assets; they will become less effective as time goes by. Conversely, accruals-based earnings management does not affect the operations of the business but merely represents alterations in the way accounting information are presented, for instance, a change in inventory valuation or depreciation methods reported.

H4: The effects of real-activities manipulations are more detrimental than accrualsbased earnings manipulations.

\footnotetext{
${ }^{1}$ A similar argument can be made for the presence of investment banks as M\&A advisors.
} 
To the extent that the effects of real activities manipulation pan out in the long run and are not immediately recognizable at the time of undertaking, the possibility exists that the market will be misled by them in the short run. Thus, we test whether the short-term market reaction to bidders' announcement of an M\&A is directly proportional to their pre-announcement level of earnings manipulation.

H5: Bidders engaged in real activities manipulations are associated with more favorable market reaction at the time of $M \& A$ announcement.

Assuming that investors are unable to detect earnings manipulation at a bidder firm prior to an M\&A announcement, they would be "surprised" about the "less-than-perfect" bidder's performance in the future and react more negatively (Richardson, Sloan, Soliman and Tuna, 2005). Thus, bidders with higher earnings management prior to M\&A announcements should experience lower long-run post-announcement returns.

H6: Bidders with higher earnings management prior to M\&A announcements will experience lower long-run post-announcement returns.

\section{Sample Selection \& Methodology}

\subsection{Sample Selection}

The sample consists of 5,857 U.S. domestic deals from 1980 to 2011. Deal information is obtained from the Thomson One Banker Deal database; stock price data are obtained from the Center for Research in Security Prices (CRSP) database; accounting data are obtained from the COMPUSTAT database. Bidder firms are U.S.-listed firms; the deal value is at least \$1 million; 
financial and utility firms with SIC codes 6000-6900 and 4900-4999 are excluded as they are heavily regulated.

Table 1 shows the sample distribution by various criteria. Starting in 1991, we observe a gradual increase in the number of M\&As with a peak in 2000. The numbers decreased drastically in 2001 and 2002; the downward trend continued thereafter and coincided with the subprime mortgage financial crisis of 2007-2009.

\section{[INSERT TABLE 1 ABOUT HERE]}

Eighty-two percent of the sample is classified as mergers and the rest as acquisitions of either majority interest, partial interest or remaining interest. We classify the latter two as "partial acquisitions" in the remainder of the paper. High-tech bidders represent $60.94 \%$ of the sample; in $34.95 \%$ of the deals, the bidder and the target share the same 4-digit SIC code; investment banks are present as advisors in $47.35 \%$ of the deals; cash only, stock-only, and mixed payment transactions represent $26.23 \%, 26.93 \%$, and $46.85 \%$ of the sample, respectively; and, the percentages of private and public targets are $43.59 \%$ and $56.41 \%$, respectively.

Deal and firm financial characteristics are summarized and presented in Table 2. The mean deal value is $\$ 565.56$ million; on average, bidder firms are 10 times larger than targets based on market values; the mean value of the premiums paid in acquisitions of public targets is $39 \%$. The number of observations for the target is lower because $46 \%$ of the sample includes private targets (with no data available in both SDC and COMPUSTAT). In Panel B of Table 2, we present size and growth statistics for matching non-bidder firms. A matched firm is one that shares the same industry and size quartile as the bidder firm and is closest in the market-to-book 
ratio but has not announced or performed an M\&A. The differences in size and market-to-book ratios between the two samples are not statistically significant.

\section{[INSERT TABLE 2 ABOUT HERE]}

\subsection{Methodology}

In this section, we describe how we measure accrual-based earnings management and real activities manipulation at bidder firms in the six quarters surrounding the M\&A announcement. We follow the methodologies of Roychowdhury (2006); Cohen, Dey and Lys (2008); Cohen and Zarowin (2010); and Zang (2012).

\subsubsection{Accruals-Based Earnings Management}

We use discretionary accruals to proxy for accrual-based earnings management. Discretionary accrual is measured as the difference between actual and forecasted accruals. We use the following modified Jones (1991) model to obtain the forecasted values:

$$
\frac{\text { Accrual }_{i, t}}{\text { Assets }_{i, t-1}}=k_{0}+k_{1} \frac{1}{\text { Assets }_{i, t-1}}+k_{2} \frac{\Delta S A L E S_{i, t}}{\text { Assets }_{i, t-1}}+k_{3} \frac{P P E_{i, t}}{\operatorname{Assets}_{i, t-1}}+\epsilon_{i, t}
$$

where, for quarter $t$ and firm $i$, Accruals represents the total accruals defined as:

$$
\text { Accruals }_{i, t}=E B X I_{i, t}-C F O_{i, t}
$$

where $E B X I$ is the earnings before extraordinary items and discontinued operations and $C F O$ is the operating cash flows (from continuing operations) taken from the statement of cash flows. Assets $_{i, t-1}$ represents total assets in quarter $t-1, \Delta S A L E S_{i, t}$ is the change in sales from the preceding quarter, and $P P E_{i, t}$ is the gross value of property, plant and equipment. The residual 
from the regression represents the extent of accruals-based earnings management. We report the results from the regression to obtain discretionary accruals in Panel A Table 3. We use the universe of Compustat firms to estimate the equations.

\section{[INSERT TABLE 3 ABOUT HERE]}

\subsubsection{Real Activities Manipulation}

We construct the following two measures of real activities manipulations: (i) abnormal level of production costs and (ii) abnormal level of discretionary expenditures. Roychowdhury (2006) finds evidence consistent with firms trying to boost sales with generous offers, to lower the cost of goods sold by overproducing and reducing discretionary expenditure to improve margins. To obtain abnormal production costs, we first estimate the normal level of production costs as follows:

$$
\begin{aligned}
& \frac{\operatorname{PROD}_{i, t}}{\operatorname{Assets}_{i, t-1}} \\
& =k_{0}+k_{1} \frac{1}{\operatorname{Asset}_{i, t-1}}+k_{2} \frac{\operatorname{SALES}_{i, t}}{\operatorname{Asset}_{i, t-1}}+k_{3} \frac{\Delta \operatorname{SALES}_{i, t}}{\operatorname{Asset~}_{i, t-1}}+k_{4} \frac{\Delta \operatorname{SALES}_{i, t-1}}{\operatorname{Asset}_{i, t-1}}+\epsilon_{i, t}
\end{aligned}
$$

where $P R O D_{i, t}$ is the sum of the cost of goods sold in quarter $t$ and the change in inventory during the quarter for firm $i$, Asset $_{i, t-1}$ is the total assets in quarter $t-1, S A L E S_{i, t}$ is the net sales in quarter $t, \triangle S A L E S_{i, t}$ and $\triangle S A L E S_{i, t-1}$ represent changes in sales during quarter $t$ and $t-1$, respectively. The equations are estimated cross-sectionally for each industry-quarter using the Fama-French (1997) 48-sector industry classification on the universe of Compustat firms. The abnormal level of production costs is measured as the estimated residual of the regression. 
To obtain abnormal discretionary expenses, we first estimate its normal level using the following equation:

$$
\frac{\operatorname{DISX}_{i, t}}{\operatorname{Assets}_{i, t-1}}=k_{0}+k_{1} \frac{1}{\operatorname{Asset}_{i, t-1}}+k_{2} \frac{\operatorname{SALES}_{i, t-1}}{\operatorname{Asset}_{i, t-1}}+\epsilon_{i, t}
$$

where $D I S X_{i, t}$ is the discretionary expenditures (i.e., the sum of research and development $(R \& D)$, advertising, and selling, general and administrative ( $S G \& A)$ expenditures) in quarter $t$, Assets $_{i, t-1}$ is the total assets in quarter $t-1$ and $S A L E S_{i, t-1}$ is the net sales in quarter $t-1$. We estimate the model for every industry in each quarter using the Fama-French (1997) 48sector industry classification. The abnormal level of discretionary expenditures is measured as the estimated residual obtained from the regression. We multiply the residuals by negative one such that higher values indicate greater cuts in the amount of discretionary expenditures to inflate earnings. We report the results from the regressions to obtain the abnormal production cost and abnormal discretionary expenditure variables in the first two models in Panel A of Table 3, respectively. We use the universe of COMPUSTAT firms to estimate the equations.

We derive a composite measure for real activities manipulation as follows:

$$
\begin{aligned}
& \text { Total Real Earnings Management Score } \\
& =\text { Score for Abnormal Production Cost } \\
& + \text { Score for Abnormal Discretionary Expenditure }
\end{aligned}
$$

The higher the amount of this aggregate measure, the more likely the firm is engaged in real activities manipulation.

\subsubsection{Unexpected Real Activities Manipulation}


Zang (2012) argues that managers consider the tradeoffs between the costs and benefits

of real activities manipulation before engaging in such activities. Therefore, we construct measures of unexpected real activities manipulation, which are the estimated residuals $\left(u_{t}\right)$ from the following equation (also see Zang (2012) for an explanation of the model and the contribution of each variable). We report the results from the regressions to obtain the measures of "unexpected" earnings management variables in Panel B Table 3.

\section{Real Activities Manipulation}

$=k_{0}+k_{1}$ Market Share $_{t-1}+k_{2}$ ZSCORE $_{t-1}+k_{3} I N S T_{t-1}+k_{4}$ SOX $_{t}+k_{5}$ NOA $_{t-1}$

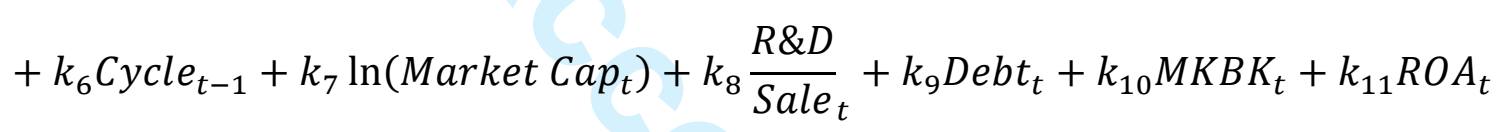

$+u_{t}$

where,

Real Activities Manipulation represents Abnormal Production Costs, Abnormal Discretionary Expense and Total Real Earnings Management in three separate regressions, respectively.

Market Share is the ratio of a company's sales-to-total sales of its industry group based on the Fama-French (1997) 48-sector industry classification; $Z S C O R E_{t}$ is a modified version of Altman's Z-score (Altman 1968, 2000), and acts as a proxy for financial condition. Higher values of ZSCORE indicate a healthier financial condition and a lower cost associated with real activities manipulation. The ZSCORE is computed as follows: 
$Z S C O R E_{t}$

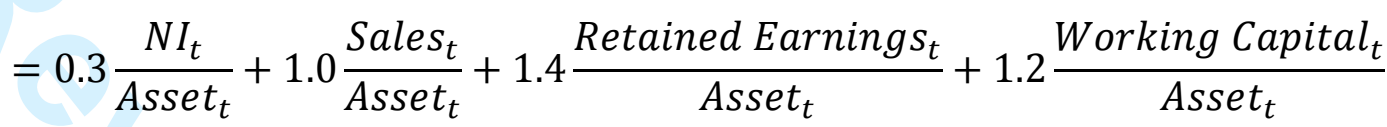

$+0.6 \frac{(\text { Stock Price } \times \text { Shares Outstanding })_{t}}{\text { Total Liabilities } \text { L }_{t}}$

$I N S T_{t-1}$ is the percentage of institutional ownership at the beginning of the quarter; $S O X_{t}$ is a dummy variable representing fiscal quarters starting in $2003 ; N O A_{t-1}$ represents net operating assets at the beginning of the quarter and serves as a proxy for the extent of accrual management in previous periods. $N O A_{t-1}$ is calculated as:

$$
\frac{\text { Shareholders' }^{E_{\text {Equit }}} \mathrm{t}_{t-1}-\text { Cash and Marketable Securities }_{t-1}+\text { Total Debt }_{t-1}}{\text { Sales }_{t-1}}
$$

Cycle $_{t-1}$ is computed as the days receivable plus the days inventory less the days payable at the beginning of the quarter; In (Market Cap $\left._{t}\right)$ represents the natural logarithm of market

capitalization; $\frac{R \& D}{\text { Sale }_{t}}$ represents the ratio of research and development expenses-to-sales; $D e b t_{t}$ is the ratio of long-term liabilities-to-market capitalization; and $R O A_{t}$ represents the return on assets.

We present the results of the above regressions for comparison purposes with previous studies in Table 3. Most of the coefficients are significant and comparable to those reported in Roychowdhury (2006) and Zang (2012). The values of the adjusted $\mathrm{R}^{2}$ range between $18 \%$ and $70 \%$. The estimated residuals from the relevant estimation models measure the abnormal levels of production costs, discretionary expenditures, and discretionary accruals. Panel C of Table 3 reports summary statistics for the proxies of real and accrual earnings management. 


\subsubsection{Multiple Regressions of Earnings Management}

Our objective is to observe the levels of accrual-based earnings management and real activities manipulations by bidders in the quarters preceding and following the M\&A announcement. To conduct this analysis the bidder firms' levels of accrual-based earnings management and real activities manipulations are calculated for six quarters preceding and following the M\&A announcement and included in the following regression model:

Earnings Management ${ }_{i, t}$

$=\alpha_{i}+\sum_{t=-6}^{+6} \beta_{1, t}$ Quarter $_{i, t}+\beta_{2} \ln \left({\text { Deal Value })_{i}}_{+}+\beta_{3}\right.$ Partial Acquisitions $_{i}$

$+\beta_{4}$ Hightech Bidders $_{i}+\beta_{5}$ Borrowed Funds $_{i}+\beta_{6}{\text { Related } \text { Target }_{i}}$

$+\beta_{7}$ Investment Bank $_{i}+\beta_{8} \%$ Cash $_{i}+\beta_{9}$ Private Targets $_{i}+\varepsilon_{i, t}$

where Quarter is a dummy variable representing the respective quarter to the quarter of the M\&A announcement, which is Quarter 0. Ln (Deal Value) is the natural logarithm of the dollar value of the deal. We use dummy variables to represent partial acquisitions, high-tech bidders, deals financed with borrowed funds, where bidder and target share the same 4-digit SIC code, where the services of an Investment Bank are used, deal where cash is the only form of payment, and private targets, respectively. Our objective is to observe in which quarter(s) the ratios of production costs-to-total asset, discretionary expenditure-to-total asset and discretionary accruals-to-total assets, i.e., our proxies for earnings management, are abnormally high. Following Petersen (2009), we estimate $p$-values in the regression models based on clustering by firm and time (i.e., quarters) to account for correlations among the error terms among firms and within the quarters. 


\section{Findings}

\subsection{Earnings Management Level at Bidder Firms}

To conduct a univariate analysis of the earnings management levels of bidder firms, we compare them to matching non-bidder firms. A matching firm shares the same industry and size quartile as the bidder firm and is closest in the market-to-book ratio, but has not announced or engaged in an M\&A. In Panel A of Table 4, we report the summary statistics of the earnings management variables in each of the 12 quarters surrounding the M\&A announcement dates. We present a graph (see Figure 1) to better illustrate the trend in real activities manipulation and accrual-based earnings management at bidder firms. There is a gradual but distinct increase in the earnings management measures leading to the quarter of the M\&A announcement (i.e., quarter 0) and a reversal in the trend post-announcement.

The $t$-tests between the mean values in the $(-4,-1)$ window and the $(-6,-5)$ window are highly significant with $t$-statistics ranging from 5.49 for Unexpected Abnormal Production Costs to 15.24 for Abnormal Discretionary Expenses. These results suggest that both accrual earnings management and real activities management are high for bidder firms during the pre-M\&A periods. In comparison, non-bidder firms show no abnormal earnings management in either accruals or real activities.

To test H1 we compare the pre-M\&A announcement $(-4,-1)$ abnormal accruals and abnormal real earnings to their corresponding values post-announcement $(+1,+6)$ period. We find the discretionary accruals exhibit a difference between the pre and post sub periods of $5.67 \%$. Similarly, the unexpected abnormal production costs difference between the two sub periods equals $1.54 \%$. The $t$-statistics are significant and equal 10.18 and 2.25 , respectively for 
the discretionary accruals and the unexpected abnormal production costs. No statistical differences between the two sub periods are found for the non-bidder firms. These results provide some supporting evidence for hypothesis $\mathrm{H} 1$ implying that pre-M\&A earnings manipulations are higher than post-M\&A earnings manipulations.

\title{
[INSERT TABLE 4 ABOUT HERE]
}

\section{[INSERT FIGURE 1 ABOUT HERE]}

\begin{abstract}
While bidder firms increase earnings management prior to the announcement and decrease it post-announcement this characteristic is not exhibited by the matched non-bidder firms. In Panel B of Table 4 the non-bidder firms exhibit no discernable pattern in their earnings management variables both before and after the M\&A announcement. Thus, bidder firms manage earnings differently from non-bidder firms.
\end{abstract}

In Table 5, we provide similar summary statistics for subsamples of cash-only vs. other forms of payment, and private vs. public targets, respectively. The $t$-test between the mean earnings management variables in the $(-4,-1)$ window and the $(-6,-5)$ window are significant for both cash bids and deals including stock payment. Thus, bidders increase earnings management prior to M\&A announcements irrespective of the method of payment. Figures 2 to 5 demonstrate the trend in real activities manipulation and accrual-based earnings management at bidder firms for the various subsamples.

[INSERT FIGURES 2 TO 5 ABOUT HERE]

\subsection{Multiple Regressions of Earnings Management}


We present the regressions of the various earnings management variables in Table 5. Included amongst the independent variables are two dummy variables representing quarters (-6 to-5) and quarters (-4 to-1), respectively, with the M\&A announcement in quarter 0 . The intercept term captures the effects of the remainder quarters. The coefficient of the dummy variables representing the relative quarters $(-4,-1)$ is positive and larger than the coefficient representing quarters $(-6,-5)$ in the regression of discretionary accruals. The coefficients representing quarters $(-6,-5)$ are consistently negative and significant in the regressions presented, unlike those representing quarters $(-4,-1)$. Taken together, the evidence suggests that bidders increase the use of earnings management as they approach the M\&A deal providing evidence in support of $\mathrm{H} 1$.

\section{[INSERT TABLE 5 ABOUT HERE]}

In other results, the coefficient of $\ln$ (Deal Value) is negative in the regression of discretionary accruals but positive in the remainder regressions where measures of real activities manipulations are the dependent variables. In fact, the real earnings manipulations coefficients are statistically significant at the $1 \%$ level, and positively related to size as measured by $\operatorname{Ln}($ Deal Value), providing support for hypothesis H3.

Deals financed with debt exhibit high earnings management scores (i.e., the coefficient of the dummy variable representing borrowed funds is positive); bidders are less likely to manage earnings upwards in acquisitions of related targets (the coefficient of the dummy variable representing related targets is negative); and, bidders buying private targets are less likely to manage earnings upwards (the coefficient of the variable representing private targets is negative). 
Nonetheless, not all the coefficient estimates of the control variables are consistent with our expectations. For instance, we expect to find that bidders manipulate earnings upwards in industries characterized by greater information asymmetry and high-tech industries. Instead, the coefficient of the dummy variable representing high-tech bidders is negative. Similarly, we expect that bidders that will pay a part of the consideration in cash are not as motivated to manage earnings to inflate stock prices. Rather, the coefficient of the variable representing the cash-only deals is positive.

In Table 6, we split the sample between cash-only deals vs. other deals. The results are qualitatively the same, i.e., there is an increase in discretionary accruals in the quarters surrounding the M\&A announcement among the bidder firms. In terms of real earnings management, the coefficient of the dummy variable representing Quarter $(-4,-1)$ is consistently larger than the coefficient of the dummy variable representing Quarter $(-6,-5)$ and is highly significant. Our results reveal the existence of high levels of earnings management in the quarters immediately preceding the M\&A announcements and surrounding the deal effective dates.

\section{[INSERT TABLE 6 ABOUT HERE]}

\subsection{Stock Price Reaction upon M\&A Announcement}

To test the stock market's assessment of earnings management at bidder firms, we calculate average abnormal returns (AARs) using two models, i.e., the market model and the Fama-French three-factor model. We estimate the parameters of the models using daily returns in the $(-8,-5)$ quarter window, with day 0 representing the day of the M\&A announcement. Average abnormal return is the average of the difference between the daily return of the bidder 
firm and the predicted daily return of the firm from either the market model or the Fama-French three-factor model, alternatively. AAR represents the average of daily abnormal returns over the $(-4,-1)$ quarters preceding the quarter of the M\&A announcement.

We present our findings in Table 7. In Panel A, average abnormal returns are presented both for the whole sample and various subsamples. In the remaining panels, we break the sample into quartiles with the first representing low values- and the fourth representing high values of earnings management. We then compare the mean AAR of the fourth quartile with the first one.

\section{[INSERT TABLE 7 ABOUT HERE]}

The mean bidder AAR over the window $(-4,-1)$ of the fourth quartile always exceeds that of the first quartile, and the difference is statistically significant in five out of the six panels. The findings suggest that the AAR of the quartile representing bidders that more aggressively manage earnings is larger than the AAR of the quartile representing bidders that manage earnings less. It would be consistent with our hypothesis, H5, stating that the short-term market reaction to bidders' announcement of an M\&A is directly proportional to the bidders' preannouncement level of earnings manipulation.

In the following section, we perform a multiple regression of the AARs using the following model: 


$$
\begin{aligned}
& A A R_{i, t} \\
& =\alpha_{i}+\beta_{1} \text { Average discretionary accruals } \text { act }_{i}+\beta_{2} \text { Total real management }_{i, t} \\
& +\beta_{3} \text { Unexpected total real earnings management }_{i, t}+\beta_{4} \ln \left(\text { Deal value }_{i, t}\right.
\end{aligned}
$$

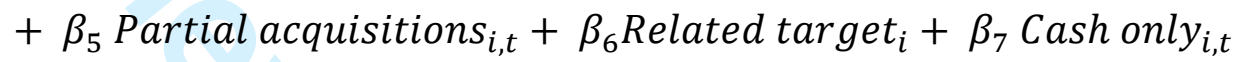

$$
\begin{aligned}
& +\beta_{8}\left(\text { Cash only } x \text { Private } \text { targets }_{i, t}\right) \\
& +\beta_{9}\left(\frac{\text { Industry adjusted operating cashflows }}{\text { assets }}_{i, t}\right)+\beta_{10} \text { Industry adjusted } m t b_{i, t} \\
& +\beta_{11} \text { Industry adjusted debt ratio }_{i, t}+\varepsilon_{i, t}
\end{aligned}
$$

where AAR is average abnormal returns using two models, i.e., the market model and the FamaFrench three-factor model in alternate regressions. Ln (Deal value) is the natural logarithm of the dollar value of the deal. We use dummy variables to represent partial acquisitions, related target (i.e., where the bidder and the target share the same 4-digit SIC code), deal where cash is the only form of payment, and private targets, respectively. Following Baik, Kang and Morton (2007), we include a dummy variable representing private targets as a control variable. The remaining independent variables include: industry adjusted operating cash flows divided by assets, industry adjusted market to book value, and industry adjusted debt ratio. We present our results in Table 8. The dependent variable is the bidder firm's AAR. The coefficients representing real earnings management in quarters -4 to -1 are positive and significant (see Models 2 and 5), suggesting that the short-run market reaction and bidder's use of real earnings management prior to the M\&A announcements are positively related. However, the coefficient representing abnormal levels of discretionary accruals is negative and not statistically significant 
(see Models 1 and 4). Thus, the ability of real activity manipulation to sway market opinion is superior to accrual-based earnings management.

\section{[INSERT TABLE 8 ABOUT HERE]}

We repeat the multivariate analysis for the four subsamples based on the method of payment and present our findings in Table 9. The coefficients representing real earnings management in quarters -4 to -1 are positive and significant only for stock-only $\&$ stock-cash, suggesting that the short-run market reaction and bidder's use of earnings management techniques prior to the M\&A announcements are positively related. The findings suggest that real activity manipulation only works for mixed payment deals. Conversely, the coefficient representing abnormal levels of discretionary accruals is either negative, not statistically significant, or both (see Models 1 and 3).

\section{[INSERT TABLE 9 ABOUT HERE]}

\subsection{Long Run Stock Price Performance}

We expect the practice of manipulating earnings to adversely affect the bidders' performance in the long run. Thus, in addition to the short-term market reaction, we also consider the bidders' long-run stock performance in the 12-, 24- and 36 months' postannouncement buy and hold returns (BHRs).

We report the raw BHRs of the bidders, the market-adjusted buy-and-hold returns (e.g. the firm's BHR minus the CRSP value-weighted BHR) and the match-firm-adjusted buy-andhold returns (e.g. the firm's BHR minus the match firm's BHR). A matched firm is a nonacquirer that is in the same size quartile and is closest in the market-to-book ratio as the bidder 
firm in the quarter preceding the M\&A announcement date. We winsorize the BHRs at the $1 \%$ and $99 \%$ percentiles. We present our findings in Table 10. In Panel A, the BHRs of the manipulating firms are consistently and significantly lower than the benchmarked ones. In Panel B, the BHRs of the most manipulating firms (i.e., Quartile 4) are consistently and significantly lower than the BHRs of the least manipulating firms (i.e., Quartile 1). The findings persist irrespective of the type of earnings management. The differences persist upon dividing the sample by the methods of payment in Panels C and D.

[INSERT TABLE 10 ABOUT HERE]

We run multiple regressions on bidders' BHARs (i.e., the difference between the BHR of the acquiring firm and the BHR of its matched counterpart) to determine the effect of preannouncement earnings manipulation activities on post-announcement stock performance and present our findings in Table 11.

\section{[INSERT TABLE 11 ABOUT HERE]}

The dependent variable in Table 11 is the bidder's BHARs. We use several proxies for earnings management including matched-adjusted discretionary accruals, matched-adjusted total real activities manipulation and matched-adjusted unexpected total real activities manipulation. The coefficients representing the various proxies for earnings manipulation in the quarters -4 to 1 are always negative, however, they are only significant for matched-adjusted total real activities manipulation and matched-adjusted unexpected total real activities manipulation. Thus, consistent with the univariate findings in Table 11, we find that bidders' long-run stock performance is inversely related to the degree of real earnings manipulations prior to the M\&A announcements. We also find that bidders' long-run stock performance is positively related to 
acquisitions of high-tech targets, cash-only financed deals, acquisitions of private targets and bidders' ratio of operating cash flows-to-total assets. Thus, in support of past studies on M\&A, we find cash-payment exhibits a statistically significant positive effect on stock returns.

\section{Conclusion}

We analyze the extent of both real activities manipulation and accrual-based earnings management at bidder firms in the quarters leading to a stock swap announcement in M\&A transactions. Our sample consists of 5,857 U.S. domestic deals between 1980 and 2011. We observe a marked increase in real activities manipulations amongst bidders in the quarters leading to an M\&A announcement. This would be consistent with the hypothesis that bidders manipulate earnings prior to M\&A announcements. In regression analysis of earnings management, the coefficient of the dummy variable representing quarters $(-4,-1)$-with quarter 0 representing the M\&A announcement - is always positive.

We contribute to the existing literature on the relationship between the M\&A underperformance puzzle and earnings management. We examine the level of real activities' manipulations, in addition to accrual based earnings management, at bidder firms before the merger. Our findings are consistent with bidders inflating earnings by engaging in real activities' manipulations to boost their share price.

Furthermore, we document a direct relationship between bidders' earnings management level prior to the M\&A and the market reaction to their stock price on the day of the M\&A announcement. We find that the short-term positive effect of real activities manipulation on bidders' share prices is stronger than accrual-based earnings management. Though, our evidence suggests that the portfolios of earnings manipulators underperform relative to the portfolios of 
non-manipulators in the long run. The post-M\&A long run stock returns of bidder firms are inversely related to their level of earnings management prior to the M\&A announcement.

The implication for market participants is that firms engage in earnings management prior to M\&As. While there may be a temporary benefit in the short-term stock price of bidders engaging in earnings management, yet such practices end up costing their shareholders dearly in the long run. The stock performance of firms engaging in earnings management underperform that of various matching control firms in the months following the M\&A. The adverse effect of earnings management is more pronounced amongst firms undertaking real activities manipulations than accruals-based earnings management. It could be due to the more severe long-term cash flow consequences of real earnings management. To assist investors in their assessments of real earnings manipulations in M\&As, future research should consider other ways to detect earnings manipulations at bidder firms, for instance, auditors' reports, accounting restatements, targeting by the SEC and Public Company Accounting Oversight Board (PCAOB) amongst others. 


\section{References}

Altman, E. 1968. Financial ratios, discriminate analysis and the prediction of corporate bankruptcy. Journal of Finance 23 (4): 589-609.

Altman, E. 2000. Predicting Financial Distress of Companies: Revisiting the Z-Score and ZETA Models. Working paper, New York University.

Baik, Bok and Kang, Jun-Koo and Morton, Richard M., Earnings Management in Takeovers of Privately Held Targets (August 2007). Available at SSRN: http://ssrn.com/abstract=1013639 or http://dx.doi.org/10.2139/ssrn.1013639

Bharadwaj, A., Shivdasani, A., 2003. Valuation effects of bank financing in acquisitions. Journal of Financial Economics 67, 113-148.

Botsari, A. and Meeks, G. (2008), Do Acquirers Manage Earnings Prior to a Share for Share Bid?. Journal of Business Finance \& Accounting, 35: 633-670.

Cohen, D., and P. Zarowin. 2010. Accrual-based and real earnings management activities around seasoned equity offerings. Journal of Accounting and Economics 50 (1): 2-19.

Cohen, D., A. Dey, and T. Lys. 2008. Real and accrual-based earnings management in the preand post-Sarbanes-Oxley period. The Accounting Review 83 (3): 757-787.

Demski, J. 1998. Performance measure manipulation, Contemporary Accounting Research 15, 261-285.

Dichev, I.D., Graham, J.R., Harvey, C.R., and Rajgopal, S. (2013) Earnings quality: Evidence from the field, Journal of Accounting and Economics, Volume 56, Issues 2-3, Supplement 1, 15 December 2013, Pages 1-33

Erickson, M. and Wang, S., 1999. Earnings Management by Acquiring Firms in Stock for Stock Mergers, Journal of Accounting and Economics 27 (2), pp. 149-76.

Fama, Eugene F. and Kenneth R. French, 1997, Industry costs of equity, Journal of Financial Economics 43, 153-193.

Gong, G., Louis, H. And Sun, A. X. (2008), Earnings Management and Firm Performance Following Open-Market Repurchases. The Journal of Finance, 63: 947-986.

Harford, J., Klasa, S. and N. Walcott, 2009. Do firms have leverage targets? Evidence from acquisitions, Journal of Financial Economics 93 (1), 1-14.

Jones, J. 1991. Earnings management during import relief investigations. Journal of Accounting Research 29 (2): 193-228.

Louis, H. 2004. Earnings management and the market performance of acquiring firms, Journal of Financial Economics 74, 121-148. 
Louis, H. and D. Robinson. 2005. Do managers credibly use accruals to signal private information? Evidence from the pricing of discretionary accruals around stock splits, Journal of Accounting and Economics 39, 361-380.

Petersen, M. 2009. Estimating standard errors in finance panel data sets: Comparing approaches, Review of Financial Studies 22, 435-480.

Richardson, S., R. Sloan, M. Soliman and I. Tuna. 2005. Accrual reliability, earnings persistence and stock prices, Journal of Accounting and Economics 39, 437-485.

Roychowdhury, S. 2006. Earnings management through real activities manipulation. Journal of Accounting and Economics 42 (3): 335-370.

Sloan, R.G., 1996. Do stock prices fully reflect information in accruals and cash flows about future earnings? Accounting Review 71, 289-315.

Subramanyam, K., 1996. The pricing of discretionary accruals, Journal of Accounting and Economics 22, 249-281.

$\mathrm{Xu}, \mathrm{R}$. and M. Lacina. 2009. Explaining the accrual anomaly by market expectations of future returns and earnings, Advances in Accounting, incorporating Advances in International Accounting 25, 190-199.

Zang, A.Y., 2012. Evidence on the Trade-Off between Real Activities Manipulation and Accrual-Based Earnings Management, Accounting Review 87, 675-703. 


\begin{tabular}{|c|c|c|c|c|}
\hline \multicolumn{5}{|c|}{ Panel A-Deal Characteristics and Target Characteristics } \\
\hline Variables & $\mathrm{N}$ & Mean & Median & $\begin{array}{l}\text { Standard } \\
\text { deviation }\end{array}$ \\
\hline Deal value & 5,857 & 565.558 & 74.999 & $2,956.758$ \\
\hline Target Market value 4 weeks prior (\$ million) & 2,188 & $1,047.104$ & 165.225 & $7,663.377$ \\
\hline Target Total Assets (\$ million) & 3,026 & 676.076 & 93.811 & $2,854.777$ \\
\hline Target ROA & 2,951 & -0.124 & 0.024 & 0.996 \\
\hline Premium1 Day & 2,020 & 0.390 & 0.285 & 1.469 \\
\hline Number of Bidders & 5,857 & 1.028 & 1.000 & 0.199 \\
\hline$\%$ cash payment & 5,857 & 36.221 & 0.000 & 44.297 \\
\hline$\%$ shares acquired & 5,687 & 88.952 & 100.000 & 25.897 \\
\hline \multicolumn{5}{|c|}{ Panel B - Bidders' and Matching Firms' Characteristics } \\
\hline Variables & $\mathrm{N}$ & Mean & Median & $\begin{array}{l}\text { Standard } \\
\text { deviation }\end{array}$ \\
\hline Bidder market value 4 weeks prior ( $\$$ million) & 5,857 & $10,767.17$ & 911.05 & $32,724.72$ \\
\hline $\begin{array}{l}\text { Non-bidder matching firms' market value } 4 \\
\text { weeks prior ( } \$ \text { million) }\end{array}$ & 4,974 & $11,369.49$ & 1080.967 & $40,542.48$ \\
\hline Difference & & -602.32 & -169.92 & \\
\hline t-stat / Wilcoxon-stat & & -1.05 & -1.12 & \\
\hline Bidder market-to-book ratio & 5,857 & 4.977 & 2.246 & 11.202 \\
\hline $\begin{array}{l}\text { Non-bidder matching firms' market-to-book } \\
\text { ratio }\end{array}$ & 4,974 & -5.870 & 2.120 & 8.618 \\
\hline Difference & & 10.847 & 0.126 & \\
\hline t-stat / Wilcoxon-stat & & -1.38 & 0.52 & \\
\hline
\end{tabular}

The sample consists of 5,857 U.S. domestic stock swap deals between 1980 and 2011. Premium1Day is the percentage difference between the deal value and the target's market value on the day preceding the M\&A announcement date. Values on deal, target and bidder characteristics are obtained from the Thomson One Deals and the Compustat database. Panel A contains descriptive statistics on the deal and target firms; Panel B on sample bidder firms and matching non-bidder firms. A matched firm is one that shares the same industry and size quartile as the bidder firm and is closest in the market-to-book ratio. 
Table 3

Regression Analysis to Measure Real activities Manipulation and Accrual-Based Earnings Management Panel A - Estimation of the Abnormal Normal Levels of Production Costs, Discretionary Expense and Discretionary Accruals

\begin{tabular}{|c|c|c|c|c|c|c|}
\hline Independent Variables & 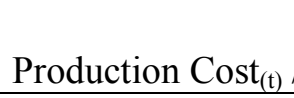 & $\operatorname{Asset}_{(t-1)}$ & $\begin{array}{l}\text { Discretic } \\
\text { Asset }_{(t-1)}\end{array}$ & Expense $_{(\mathrm{t})} /$ & $\begin{array}{l}\text { Discret } \\
\text { Asset }_{(t-}\end{array}$ & $\operatorname{Accrual}_{(\mathrm{t})} /$ \\
\hline Intercept & -0.308 & -1.04 & -0.124 & -1.46 & -0.678 & $-7.810 * * *$ \\
\hline $1 /$ Asset $_{(t-1)}$ & 0.061 & $4.59 * * *$ & 0.461 & $13.15^{* * *}$ & 0.119 & $12.210 * * *$ \\
\hline Sales $_{(\mathrm{t})} / \operatorname{Asset}_{(\mathrm{t}-1)}$ & 0.720 & $171.33 * * *$ & & & & \\
\hline $\operatorname{Sales}_{(\mathrm{t}-1)} / \operatorname{Asset}_{(\mathrm{t}-1)}$ & & & 0.307 & $10.35 * * *$ & & \\
\hline$\Delta \operatorname{Sales}_{(\mathrm{t})} / \operatorname{Asset}_{(\mathrm{t}-1)}$ & -0.011 & -1.36 & & & 5.674 & $9.570 * * *$ \\
\hline$\Delta$ Sales $_{(\mathrm{t}-1)} /$ Asset $_{(\mathrm{t}-1)}$ & -0.021 & $-2.93 * * *$ & & & & \\
\hline $\operatorname{PPE}_{(t)} / \operatorname{Asset}_{(t-1)}$ & & & & & 0.288 & $8.980 * * *$ \\
\hline Mean Adj. R-squared & $69.77 \%$ & & $39.71 \%$ & & $23.86 \%$ & \\
\hline Mean \# of observations & 201.5 & & 191.48 & & 176.5 & \\
\hline \# industry-quarters & 3,784 & & 3,784 & & 3,894 & \\
\hline
\end{tabular}

Panel B - Estimation of the Unexpected Abnormal Production Costs, Discretionary Expense and Total Real Earnings Management

\begin{tabular}{|c|c|c|c|c|c|c|}
\hline \multirow{2}{*}{$\begin{array}{l}\text { Independent Variables } \\
\text { Intercept }\end{array}$} & \multicolumn{2}{|c|}{ 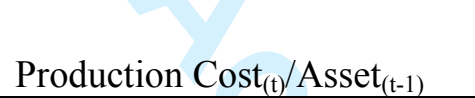 } & \multicolumn{2}{|c|}{$\begin{array}{l}\text { Discretionary } \\
\text { Expense }_{(\mathrm{t} /} / \text { Asset }_{(\mathrm{t}-1)}\end{array}$} & \multicolumn{2}{|c|}{$\begin{array}{l}\text { Total Real Earnings } \\
\text { Management }_{(t)}\end{array}$} \\
\hline & -0.013 & $-7.50 * * *$ & -0.002 & -1.23 & -0.012 & $-4.53 * * *$ \\
\hline Market share $_{(\mathrm{t}-1)}$ & 0.006 & $5.77 * * *$ & 0.041 & $37.50 * * *$ & 0.028 & $26.16 * * *$ \\
\hline ZScore $_{(\mathrm{t}-1)}$ & 0.001 & 0.67 & -0.006 & $-5.33 * * *$ & -0.003 & $-3.18 * * *$ \\
\hline $\operatorname{INST}_{(\mathrm{t}-1)}$ & -0.023 & $-20.64 * * *$ & 0.008 & $7.54 * * *$ & -0.009 & $-8.17 * * *$ \\
\hline SOX & -0.003 & $-3.13 * * *$ & 0.002 & $1.73 * * *$ & 0.000 & 0.38 \\
\hline $\mathrm{NOA}_{(\mathrm{t}-1)}$ & 0.004 & $4.14 * * *$ & 0.005 & $4.40 * * *$ & 0.004 & $3.93 * * *$ \\
\hline $\operatorname{Cycle}_{(t-1)}$ & 0.011 & $10.35 * * *$ & 0.018 & $16.44 * * *$ & 0.018 & $16.66 * * *$ \\
\hline Ln market $\operatorname{cap}_{(\mathrm{t})}$ & 0.009 & $7.64 * * *$ & -0.009 & $-7.65 * * *$ & -0.002 & -1.41 \\
\hline $\mathrm{R} \& \mathrm{D}$ expense/sale $(\mathrm{t})$ & 0.033 & $30.82 * * *$ & 0.007 & $6.31 * * *$ & 0.025 & $23.22 * * *$ \\
\hline Debt ratio $_{(\mathrm{t})}$ & 0.009 & $7.75 * * *$ & -0.010 & $-8.89 * * *$ & 0.002 & 1.49 \\
\hline $\mathrm{MKBK}_{(\mathrm{t})}$ & 0.000 & 0.3 & -0.003 & $-2.89 * * *$ & -0.002 & -1.63 \\
\hline $\mathrm{ROA}_{(\mathrm{t})}$ & -0.009 & $-7.70 * * *$ & 0.015 & $13.40 * * *$ & 0.005 & $4.59 * * *$ \\
\hline F-stat & $162.30 * * *$ & & $207.27 * * *$ & & $147.58^{*}$ & \\
\hline Adj. R-squared & 0.23 & & 0.26 & & 0.18 & \\
\hline $\mathrm{N}$ & 878,263 & & 878,263 & & 878,263 & \\
\hline \multicolumn{7}{|c|}{ Panel C - Summary Statistics for Real Activities Manipulation and Accrual-Based Earnings Management } \\
\hline \multicolumn{4}{|c|}{ Variables } & $\mathrm{N}$ & Mean & Median \\
\hline \multicolumn{4}{|c|}{ Discretionary accruals } & 5,316 & 0.014 & -0.003 \\
\hline \multicolumn{4}{|c|}{ Abnormal Production Costs } & 5,857 & -0.067 & -0.098 \\
\hline \multicolumn{4}{|c|}{ Abnormal Discretionary Expense } & 5,857 & 0.020 & 0.095 \\
\hline \multicolumn{4}{|c|}{ Total Real Earnings Management } & 5,857 & -0.045 & -0.015 \\
\hline \multicolumn{4}{|c|}{ Unexpected Abnormal Production Costs } & 5,857 & -0.063 & -0.097 \\
\hline \multicolumn{4}{|c|}{ Unexpected Abnormal Discretionary Expense } & 5,857 & 0.010 & 0.095 \\
\hline \multicolumn{4}{|c|}{ Unexpected Total Real Earnings Management } & 5,857 & -0.031 & -0.006 \\
\hline
\end{tabular}

The regressions are estimated cross-sectionally for each industry-quarter for the period 1980-2011 using the universe of firms in Compustat. The Fama-French 48 industry grouping is used. The reported coefficients are the mean values of the coefficients across industry-quarters. T-statistics are calculated using the standard errors of the coefficients across industry-quarters. The adjusted $\mathrm{R}^{2}$ (number of observations) is the mean adjusted $\mathrm{R}^{2}$ (number of observations) across industry-quarters.*,**,*** represent significance at 10 percent, 5 percent, and 1 percent levels, respectively. 
Table 4 - Comparing Earnings Management Activities Around M\&A Announcements - Whole Sample

Panel A - Earnings Management Activities Around M\&A Announcements by Sample Bidder Firms

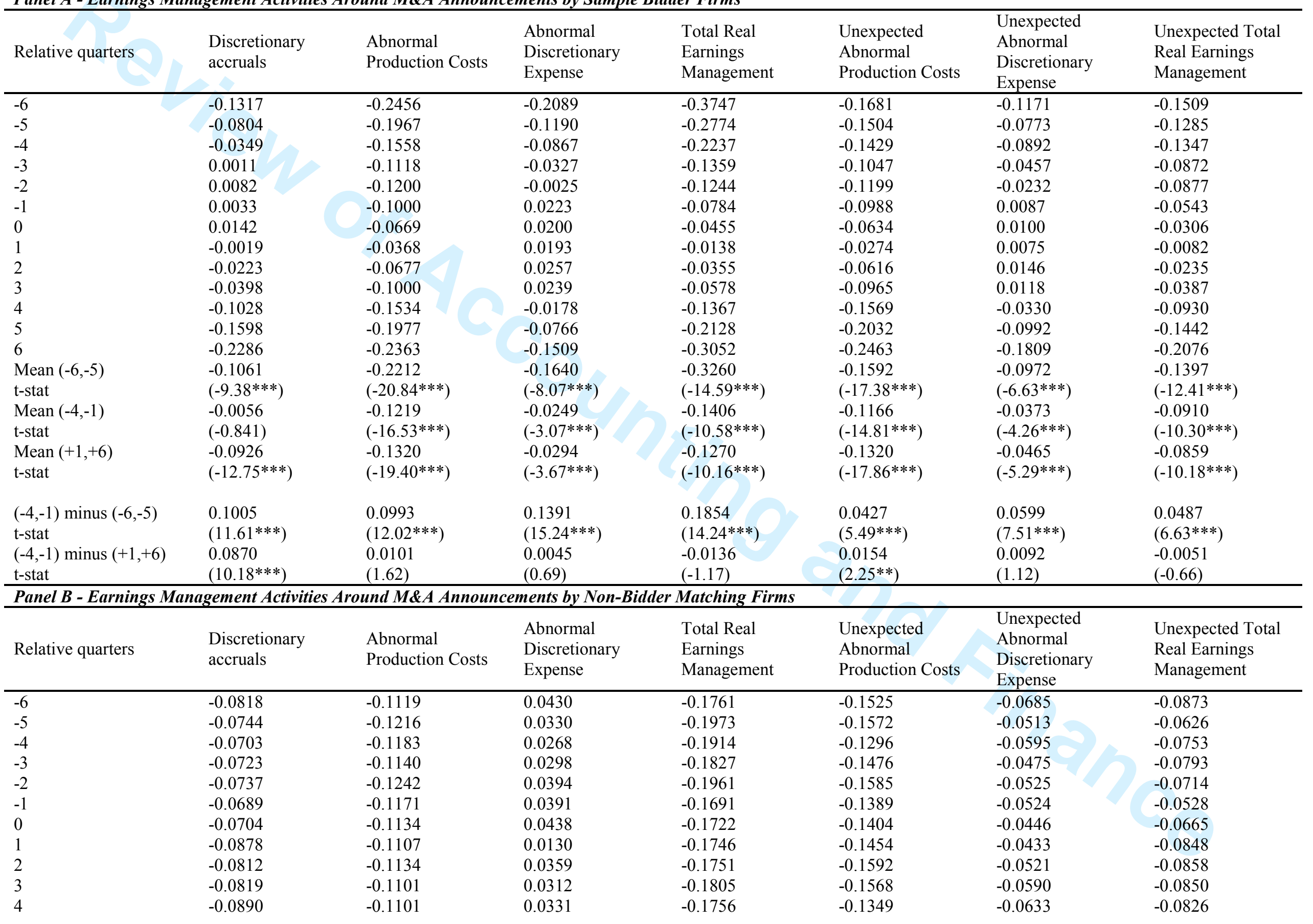




\section{Review of Accounting and Finance}

$\begin{array}{ll}5 & -0.0809 \\ 6 & -0.0904 \\ \text { Mean }(-6,-5) & -0.0781 \\ \text { t-stat } & (-9.42 * * *) \\ \text { Mean }(-4,-1) & -0.0713 \\ \text { t-stat } & (-7.24 * * *) \\ \text { Mean }(+1,+6) & -0.0852 \\ \text { t-stat } & (-16.07 * * *) \\ & \\ (-4,-1) \text { minus }(-6,-5) & 0.0068 \\ \text { t-stat } & (0.73)\end{array}$

$\begin{array}{ll}-0.1171 & 0.0440 \\ -0.1170 & 0.0389 \\ -0.1167 & 0.0380 \\ (-17.49 * * *) & (6.15 * * *) \\ -0.1184 & 0.0338 \\ (-15.82 * * *) & (3.68 * * *) \\ -0.1131 & 0.0327 \\ (-21.09 * * *) & (6.98 * * *)\end{array}$

$-0.1821$

$-0.1423$

$-0.1449$

$-0.0678$

$-0.0596$

$-0.0800$

$-0.1800$

$-0.1548$

$-0.0599$

$-0.0652$

$(6.15 * * *)$

$(-12.42 * * *)$

$-0.1848$

$(-6.68 * * *)$

$(-15.65 * * *)$

$(-5.22 * * *)$

$-0.1437$

$-0.1780$

$(-14.97 * * *)$

$-0.0530$

$(-1.95 * * *)$

$-0.1472$

$-0.0575$

$(-13.44 * * *)$

$(-20.40 * * *)$

$(-8.63 * * *)$

$-0.0749$

$(-11.40 * * *)$

$-0.0697$

$(-7.17 * * *)$

$-0.0806$

$-0.0042$

$-0.0017$

0.0018

0.0112

0.0069

$(-7.18 * * *)$

$(-4,-1)$ minus $(+1,+6)$

$(-0.01)$

$(-0.067)$

$(0.35)$

(0.80)

(0.48)

0.0045

0.0052

0.0139
$(0.37)$

$(-0.19)$

(0.49)

$(-0.28)$

$(0.44)$

(0.11)

$(0.69)$

0.0109

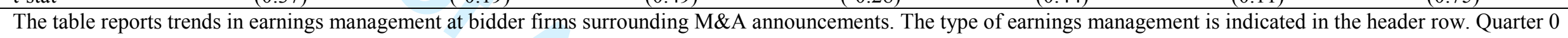

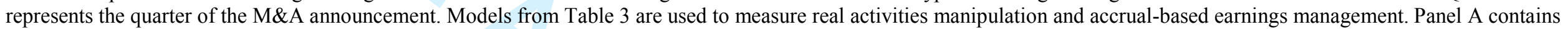

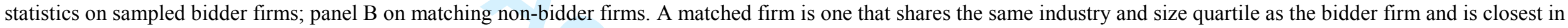
the market-to-book ratio.*,**,*** represent significance at 10 percent, 5 percent, and 1 percent levels, respectively. 
Table 5 - Cross Sectional Analyses of Earnings Management Activities

\begin{tabular}{|c|c|c|c|c|c|}
\hline Independent Variables & $\begin{array}{l}\text { Discretionary } \\
\text { accruals }\end{array}$ & $\begin{array}{l}\text { Abnormal } \\
\text { Production } \\
\text { Cost }\end{array}$ & $\begin{array}{l}\text { Abnormal } \\
\text { Discretionary } \\
\text { Expense }\end{array}$ & $\begin{array}{l}\text { Total Real } \\
\text { Earnings } \\
\text { Management }\end{array}$ & $\begin{array}{l}\text { Unexpected Total } \\
\text { Real Earnings } \\
\text { Management }\end{array}$ \\
\hline \multirow[t]{2}{*}{ Intercept } & 0.125 & 0.018 & -0.071 & -0.018 & -0.020 \\
\hline & $(3.199 * * *)$ & $(0.488)$ & $\left(-1.809^{*}\right)$ & $(-0.269)$ & $(-0.448)$ \\
\hline \multirow[t]{2}{*}{ Quarter $(-6,-5)$} & -0.012 & -0.047 & -0.062 & -0.060 & -0.027 \\
\hline & $\left(-1.955^{*}\right)$ & $(-8.590 * * *)$ & $\left(-8.996^{* * *}\right)$ & $\left(-9.818^{* * *}\right)$ & $(-5.212 * * *)$ \\
\hline \multirow[t]{2}{*}{ Quarter $(-4,-1)$} & 0.045 & 0.000 & -0.001 & -0.009 & -0.007 \\
\hline & $(8.404 * * *)$ & $(0.106)$ & $(-0.289)$ & $(-1.924 *)$ & $(-1.478)$ \\
\hline \multirow[t]{2}{*}{ Ln (Deal Value) } & -0.053 & -0.001 & 0.071 & 0.041 & 0.037 \\
\hline & $(-3.396 * * *)$ & $(-0.091)$ & $(5.721 * * *)$ & $(2.829 * * *)$ & $(2.578 * * *)$ \\
\hline \multirow[t]{2}{*}{ Partial Acquisitions } & -0.053 & -0.013 & 0.040 & 0.019 & 0.013 \\
\hline & $(-4.200 * * *)$ & $(-1.114)$ & $\left(3.776^{* * *}\right)$ & $(1.629)$ & $(1.121)$ \\
\hline \multirow[t]{2}{*}{ High-tech Bidders } & -0.077 & -0.117 & -0.068 & -0.113 & -0.106 \\
\hline & $(-4.703 * * *)$ & $\left(-7.655^{* * *}\right)$ & $\left(-4.753^{* * *}\right)$ & $(-7.032 * * *)$ & $(-6.519 * * *)$ \\
\hline \multirow[t]{2}{*}{ Borrowed Funds } & 0.013 & 0.023 & 0.018 & 0.026 & 0.025 \\
\hline & $(1.292)$ & $(2.549 * *)$ & $(2.163 * *)$ & $(2.825 * * *)$ & $(2.642 * * *)$ \\
\hline \multirow[t]{2}{*}{ Related Target } & -0.033 & -0.037 & -0.014 & -0.031 & -0.027 \\
\hline & $(-2.868 * * *)$ & $(-3.358 * * *)$ & $(-1.264)$ & $\left(-2.615^{* * *}\right)$ & $(-2.222 * *)$ \\
\hline \multirow[t]{2}{*}{ Investment Bank } & 0.026 & 0.012 & -0.040 & -0.016 & -0.015 \\
\hline & $(1.710 *)$ & $(0.914)$ & $(-3.171 * * *)$ & $(-1.161)$ & $(-1.098)$ \\
\hline \multirow[t]{2}{*}{ Cash only } & -0.003 & -0.004 & 0.054 & 0.031 & 0.028 \\
\hline & $(-0.208)$ & $(-0.311)$ & $\left(4.748^{* * *}\right)$ & $(2.399 * *)$ & $(2.159 * *)$ \\
\hline \multirow[t]{2}{*}{ Private Target } & 0.005 & -0.019 & -0.058 & -0.043 & -0.036 \\
\hline & $(0.322)$ & $(-1.556)$ & $(-4.739 * * *)$ & $(-3.330 * * *)$ & $(-2.748 * * *)$ \\
\hline \multirow[t]{2}{*}{ Private* Cash only } & -0.005 & 0.004 & 0.008 & 0.008 & 0.006 \\
\hline & $(-0.357)$ & $(0.328)$ & $(0.603)$ & $(0.535)$ & $(0.421)$ \\
\hline & & & & & \\
\hline F-stat & $22.32 * * *$ & $20.52 * * *$ & $25.80 * * *$ & $22.58 * * *$ & $11.72 * * *$ \\
\hline Adj. R-squared & 0.0132 & 0.0183 & 0.0243 & 0.0245 & 0.0183 \\
\hline Clustered std err. by firm & Yes & Yes & Yes & Yes & Yes \\
\hline $\mathrm{N}$ & 69,890 & 76,105 & 76,105 & 76,105 & 76,127 \\
\hline
\end{tabular}

The table reports regression estimates of earnings manipulation at bidder firms. The dependent variable is a measure of earnings management as indicated in the header row. We include two dummy variables representing quarters (-6 to-5), quarters (-4 to-1), respectively, with the M\&A announcement in quarter 0 . The effect of quarters $(+1,+6)$ is captured by the intercept. $\operatorname{Ln}$ (Deal Value) is the natural logarithm of the dollar value of the deal; we use dummy variables to represent partial acquisitions, high-tech bidders, deals financed with borrowed funds, where bidder and target share the same 4-digit SIC code, where the services of an Investment Bank is used, deal where cash is the only form of payment and private targets, respectively. The t-statistics are given in parentheses and are adjusted for heteroskedasticity and for clustering by firm.*,** and ${ }^{* * *}$ represent significance at 10 percent, 5 percent, and 1 percent levels, respectively. 
Table 6 - Cross Sectional Analyses of Earnings Management Activities by Subsamples based on the Methods of Payment

\begin{tabular}{|c|c|c|c|c|c|c|}
\hline \multirow[b]{2}{*}{ Independent Variables } & \multicolumn{2}{|c|}{$\begin{array}{l}\text { Panel A-Discretionary } \\
\text { accruals } \\
\text { Stock only \& }\end{array}$} & \multicolumn{2}{|c|}{$\begin{array}{l}\text { Panel B - Total Real } \\
\text { Earnings Management } \\
\text { Stock only \& }\end{array}$} & \multicolumn{2}{|c|}{$\begin{array}{l}\text { Panel C-Unexpected Total } \\
\text { Real Earnings Management } \\
\text { Stock only \& }\end{array}$} \\
\hline & Stock-Cash & Cash only & Stock-Cash & Cash only & Stock-Cash & Cash only \\
\hline Intercept & $\begin{array}{l}0.173 \\
(3.737 * * *)\end{array}$ & $\begin{array}{l}-0.010 \\
(-0.214)\end{array}$ & $\begin{array}{l}0.017 \\
(0.239)\end{array}$ & $\begin{array}{l}-0.022 \\
(-0.232)\end{array}$ & $\begin{array}{l}0.003 \\
(0.066)\end{array}$ & $\begin{array}{l}-0.027 \\
(-0.435)\end{array}$ \\
\hline Quarter $(-6,-5)$ & $\begin{array}{l}-0.012 \\
(-1.763 *)\end{array}$ & $\begin{array}{l}-0.011 \\
(-1.104)\end{array}$ & $\begin{array}{l}-0.076 \\
(-10.462 * * *)\end{array}$ & $\begin{array}{l}-0.009 \\
(-0.986)\end{array}$ & $\begin{array}{l}-0.038 \\
\left(-6.185^{* * *}\right)\end{array}$ & $\begin{array}{l}0.011 \\
(1.576)\end{array}$ \\
\hline Quarter $(-4,-1)$ & $\begin{array}{l}0.049 \\
(8.043 * * *)\end{array}$ & $\begin{array}{l}0.033 \\
(3.627 * * *)\end{array}$ & $\begin{array}{l}-0.020 \\
(-3.445 * * *)\end{array}$ & $\begin{array}{l}0.026 \\
(3.723 * * *)\end{array}$ & $\begin{array}{l}-0.017 \\
\left(-2.955^{* * *}\right)\end{array}$ & $\begin{array}{l}0.026 \\
(3.623 * * *)\end{array}$ \\
\hline Ln(Deal Value) & $\begin{array}{l}-0.071 \\
\left(-3.905^{* * *}\right)\end{array}$ & $\begin{array}{l}-0.001 \\
(-0.030)\end{array}$ & $\begin{array}{l}0.041 \\
(2.602 * * *)\end{array}$ & $\begin{array}{l}0.028 \\
(1.126)\end{array}$ & $\begin{array}{l}0.037 \\
\left(2.345^{* *}\right)\end{array}$ & $\begin{array}{l}0.026 \\
(1.045)\end{array}$ \\
\hline Partial Acquisitions & $\begin{array}{l}-0.048 \\
(-3.418 * * *)\end{array}$ & $\begin{array}{l}-0.062 \\
\left(-3.096^{* * *}\right)\end{array}$ & $\begin{array}{l}0.018 \\
(1.562)\end{array}$ & $\begin{array}{l}0.026 \\
(1.026)\end{array}$ & $\begin{array}{l}0.012 \\
(0.993)\end{array}$ & $\begin{array}{l}0.023 \\
(0.894)\end{array}$ \\
\hline High-tech Bidders & $\begin{array}{l}-0.090 \\
(-5.087 * * *)\end{array}$ & $\begin{array}{l}-0.042 \\
(-1.671 *)\end{array}$ & $\begin{array}{l}-0.131 \\
(-7.817 * * *)\end{array}$ & $\begin{array}{l}-0.051 \\
(-1.771 *)\end{array}$ & $\begin{array}{l}-0.124 \\
(-7.273 * * *)\end{array}$ & $\begin{array}{l}-0.044 \\
(-1.520)\end{array}$ \\
\hline Borrowed Funds & $\begin{array}{l}0.019 \\
(1.774 *)\end{array}$ & $\begin{array}{l}0.002 \\
(0.088)\end{array}$ & $\begin{array}{l}0.034 \\
\left(3.669^{* * *}\right)\end{array}$ & $\begin{array}{l}0.019 \\
(0.883)\end{array}$ & $\begin{array}{l}0.033 \\
(3.454 * * *)\end{array}$ & $\begin{array}{l}0.017 \\
(0.800)\end{array}$ \\
\hline Related Target & $\begin{array}{l}-0.033 \\
(-2.492 * *)\end{array}$ & $\begin{array}{l}-0.033 \\
(-1.678 *)\end{array}$ & $\begin{array}{l}-0.034 \\
(-2.634 * * *)\end{array}$ & $\begin{array}{l}-0.017 \\
(-0.803)\end{array}$ & $\begin{array}{l}-0.031 \\
(-2.323 * *)\end{array}$ & $\begin{array}{l}-0.010 \\
(-0.487)\end{array}$ \\
\hline Investment Bank & $\begin{array}{l}0.036 \\
(2.063 * *)\end{array}$ & $\begin{array}{l}-0.003 \\
(-0.140)\end{array}$ & $\begin{array}{l}-0.008 \\
(-0.523)\end{array}$ & $\begin{array}{l}-0.035 \\
(-1.474)\end{array}$ & $\begin{array}{l}-0.008 \\
(-0.518)\end{array}$ & $\begin{array}{l}-0.031 \\
(-1.339)\end{array}$ \\
\hline Private Target & $\begin{array}{l}0.002 \\
(0.128)\end{array}$ & $\begin{array}{l}0.004 \\
(0.200)\end{array}$ & $\begin{array}{l}-0.037 \\
(-2.954 * * *)\end{array}$ & $\begin{array}{l}-0.044 \\
(-1.793 *)\end{array}$ & $\begin{array}{l}-0.030 \\
(-2.427 * *)\end{array}$ & $\begin{array}{l}-0.036 \\
(-1.479)\end{array}$ \\
\hline F-stat & $25.18 * * *$ & $5.58 * * *$ & $28.04 * * *$ & $4.65 * * *$ & $15.40 * * *$ & $2.50 * * *$ \\
\hline Adj. R-squared & 0.0168 & 0.00657 & 0.0295 & 0.00714 & 0.0224 & 0.00505 \\
\hline Clustered std err. by firm & Yes & Yes & Yes & Yes & Yes & Yes \\
\hline $\mathrm{N}$ & 51,078 & 18,812 & 56,142 & 19,963 & 56,164 & 19,963 \\
\hline
\end{tabular}

The table reports regression estimates of earnings manipulation at bidder firms. We present the results by methods of payments: mixed (stock and cash) and stock-only, respectively. The dependent variable is a measure of earnings management as indicated in the header row. We include two dummy variables representing quarters ( -6 to-5), quarters (-4 to-1), respectively, with the M\&A announcement in quarter 0 . The effect of quarters $(+1,+6)$ is captured by the intercept. $\mathrm{Ln}$ (Deal Value) is the natural logarithm of the dollar value of the deal; we use dummy variables to represent partial acquisitions, high-tech bidders, deals financed with borrowed funds, where bidder and target share the same 4-digit SIC code, where the services of an Investment Bank is used, deal where cash is the only form of payment and private targets, respectively. The t-statistics are given in parentheses and are adjusted for heteroskedasticity and for clustering by firm. $*, * *, * * *$ represent significance at 10 percent, 5 percent, and 1 percent levels, respectively. 
Table 7 - Analysis of Bidder AAR $(-1,+1)$ by Quartiles Based on Bidder Level of Earnings Management Panel A - Summary Statistics of AARs

\begin{tabular}{llllll} 
Subsamples & Variables & Mean & Median & t-stat & Wilcoxon-stat \\
\hline Whole & Market model AAR & $0.308 \%$ & $0.100 \%$ & $1.77 *$ & 1.42 \\
sample & Fama-French three-factor model AAR & $0.205 \%$ & $-0.126 \%$ & 1.22 & 0.58 \\
& Market model AAR & $0.729 \%$ & $0.454 \%$ & $2.97 * * *$ & $2.68^{* * *}$ \\
Cash only & Fama-French three-factor model AAR & $0.491 \%$ & $0.097 \%$ & $2.03 * *$ & $2.39^{* *}$ \\
Stock only \& & Market model AAR & $0.158 \%$ & $-0.131 \%$ & 0.72 & -0.21 \\
Stock-cash & Fama-French three-factor model AAR & $0.103 \%$ & $-0.229 \%$ & 0.49 & -0.09
\end{tabular}

\section{Panel B - Bidders AARs by Quartiles of Earnings Management in Quarters (-4,-1) - Whole Sample}

Discretionary accruals

\begin{tabular}{|c|c|c|c|c|c|c|}
\hline Quartiles & $\begin{array}{l}\text { Market model } \\
\text { AAR }\end{array}$ & $\begin{array}{l}\text { Fama-French } \\
\text { three-factor } \\
\text { model AAR }\end{array}$ & $\begin{array}{l}\text { Market model } \\
\text { AAR }\end{array}$ & $\begin{array}{l}\text { Fama-French } \\
\text { three-factor } \\
\text { model AAR }\end{array}$ & $\begin{array}{l}\text { Market model } \\
\text { AAR }\end{array}$ & $\begin{array}{l}\text { Fama-French } \\
\text { three-factor } \\
\text { model AAR }\end{array}$ \\
\hline 1 & $0.302 \%$ & $0.206 \%$ & $-0.520 \%$ & $-0.484 \%$ & $-0.543 \%$ & $-0.522 \%$ \\
\hline 2 & $-0.114 \%$ & $-0.116 \%$ & $-0.001 \%$ & $-0.009 \%$ & $0.062 \%$ & $0.078 \%$ \\
\hline 3 & $-0.054 \%$ & $-0.044 \%$ & $0.697 \%$ & $0.439 \%$ & $0.762 \%$ & $0.467 \%$ \\
\hline 4 & $1.053 \%$ & $0.741 \%$ & $1.058 \%$ & $0.877 \%$ & $0.950 \%$ & $0.797 \%$ \\
\hline (4) minus (1) & $0.751 \%$ & $0.534 \%$ & $1.578 \%$ & $1.362 \%$ & $1.493 \%$ & $1.319 \%$ \\
\hline t-stat & 1.3 & 0.97 & $2.92 * * *$ & $2.62 * * *$ & $2.77 * * *$ & $2.55 * * *$ \\
\hline Wilcoxon stat & $1.79 *$ & 1.49 & $3.09 * * *$ & $2.75 * * *$ & $2.82 * * *$ & $2.59 * * *$ \\
\hline
\end{tabular}

Unexpected total real earnings management

Market model

Fama-French model AAR

$-0.522 \%$

$1.319 \%$

$2.59 * * *$

Panel C - Bidders AARs by Quartiles of Earnings Management in Quarters (-4,-1) - Cash-Only Subsample

Discretionary accruals

\begin{tabular}{lllllll} 
Quartiles & $\begin{array}{l}\text { Market model } \\
\text { AAR }\end{array}$ & $\begin{array}{l}\text { Fama-French } \\
\text { three-factor } \\
\text { model AAR }\end{array}$ & $\begin{array}{l}\text { Market model } \\
\text { AAR }\end{array}$ & $\begin{array}{l}\text { Fama-French } \\
\text { three-factor } \\
\text { model AAR }\end{array}$ & $\begin{array}{l}\text { Market model } \\
\text { AAR }\end{array}$ & $\begin{array}{l}\text { Fama-French } \\
\text { three-factor } \\
\text { model AAR }\end{array}$ \\
\hline 1 & $0.521 \%$ & $0.314 \%$ & $0.074 \%$ & $-0.016 \%$ & $0.372 \%$ & $0.246 \%$ \\
2 & $0.708 \%$ & $0.532 \%$ & $0.309 \%$ & $0.112 \%$ & $0.143 \%$ & $-0.004 \%$ \\
3 & $-0.063 \%$ & $-0.331 \%$ & $1.210 \%$ & $0.811 \%$ & $1.279 \%$ & $0.839 \%$ \\
4 & $1.688 \%$ & $1.346 \%$ & $1.082 \%$ & $0.886 \%$ & $1.001 \%$ & $0.817 \%$ \\
$(4)$ minus (1) & $1.167 \%$ & $1.031 \%$ & $1.007 \%$ & $0.902 \%$ & $0.629 \%$ & $0.571 \%$ \\
t-stat & 1.36 & 1.46 & $2.41 * *$ & $2.11 * *$ & $2.33 * *$ & $2.07 * *$ \\
Wilcoxon stat & 1.57 & 1.12 & $2.33 * *$ & $1.94 *$ & $2.18 * *$ & $1.82 *$
\end{tabular}
management
Total real earnings management Market model $0.074 \%$

$0.309 \%$ $1.007 \%$ Panel D - Bidders AARs by Quartiles of Earnings Management in Quarters (-4,-1) - Stock-Only \& Stock-Cash Subsample

Unexpected total real earnings

\begin{tabular}{|c|c|c|c|c|c|c|}
\hline \multirow[b]{2}{*}{ Quartiles } & \multicolumn{2}{|c|}{ Discretionary accruals } & \multicolumn{2}{|c|}{ Total real earnings management } & \multicolumn{2}{|c|}{$\begin{array}{l}\text { Unexpected total real earnings } \\
\text { management }\end{array}$} \\
\hline & $\begin{array}{l}\text { Market model } \\
\text { AAR }\end{array}$ & $\begin{array}{l}\text { Fama-French } \\
\text { three-factor } \\
\text { model AAR }\end{array}$ & $\begin{array}{l}\text { Market model } \\
\text { AAR }\end{array}$ & $\begin{array}{l}\text { Fama-French } \\
\text { three-factor } \\
\text { model AAR }\end{array}$ & $\begin{array}{l}\text { Market model } \\
\text { AAR }\end{array}$ & $\begin{array}{l}\text { Fama-French } \\
\text { three-factor } \\
\text { model AAR }\end{array}$ \\
\hline 1 & $0.230 \%$ & $0.171 \%$ & $-0.647 \%$ & $-0.584 \%$ & $-0.739 \%$ & $-0.687 \%$ \\
\hline 2 & $-0.474 \%$ & $-0.400 \%$ & $-0.135 \%$ & $-0.061 \%$ & $0.027 \%$ & $0.114 \%$ \\
\hline 3 & $-0.051 \%$ & $0.082 \%$ & $0.472 \%$ & $0.275 \%$ & $0.537 \%$ & $0.306 \%$ \\
\hline 4 & $0.875 \%$ & $0.571 \%$ & $1.050 \%$ & $0.874 \%$ & $0.932 \%$ & $0.790 \%$ \\
\hline (4) minus (1) & $0.646 \%$ & $0.401 \%$ & $1.696 \%$ & $1.458 \%$ & $1.671 \%$ & $1.477 \%$ \\
\hline t-stat & 0.91 & 0.61 & $2.69 * * *$ & $2.42 * *$ & $2.53 * *$ & $2.34 * *$ \\
\hline Wilcoxon stat & 1.46 & 1.19 & $2.76^{* * *}$ & $2.45 * *$ & $2.42 * *$ & $2.31 * *$ \\
\hline
\end{tabular}

The table reports mean values for bidders' average abnormal returns for the whole sample in Panel A and each of the subsamples in Panels B through E. AAR is the average of the difference between the daily return of the bidder firm and the predicted daily return of the firm from either the market model or the Fama-French 3-factor model, alternatively. We estimate the parameters of the models using daily returns in the $(-8,-5)$ quarters window, with day 0 representing the quarter of the M\&A announcement. AAR represents the average of daily abnormal returns over the $(-4,-1)$ quarters preceding the quarter of the M\&A announcement. We break the sample into quartiles with the first representing low values- and the fourth representing high values of earnings management. ${ }^{* * *}, * *$, and ${ }^{*}$ stand for statistical significance at the $1 \%, 5 \%$, and $10 \%$ level, respectively. 
Table 8 - Cross-Sectional Analyses of Bidders' AARs

\begin{tabular}{|c|c|c|c|c|c|c|}
\hline \multirow[b]{2}{*}{ Independent Variables } & \multicolumn{3}{|c|}{ Panel A - Market Model AARs } & \multicolumn{3}{|c|}{ Panel B - Fama-French 3-Factor Model AARs } \\
\hline & Model 1 & Model 2 & Model 3 & Model 4 & Model 5 & Model 6 \\
\hline Intercept & $\begin{array}{l}-0.022 \\
(-1.291)\end{array}$ & $\begin{array}{l}-0.041 \\
(-2.017 * *)\end{array}$ & $\begin{array}{l}-0.041 \\
(-2.009 * *)\end{array}$ & $\begin{array}{l}-0.037 \\
(-2.215 * *)\end{array}$ & $\begin{array}{l}-0.044 \\
(-2.208 * *)\end{array}$ & $\begin{array}{l}-0.043 \\
(-2.195 * *)\end{array}$ \\
\hline $\begin{array}{l}\text { Average Discretionary Accruals in Quarters (- } \\
4,-1)\end{array}$ & $\begin{array}{l}-0.003 \\
(-0.167)\end{array}$ & & & $\begin{array}{l}-0.007 \\
(-0.425)\end{array}$ & & \\
\hline $\begin{array}{l}\text { Total Real Earnings Management in Quarters } \\
(-4,-1)\end{array}$ & & $\begin{array}{l}0.037 \\
(2.164 * *)\end{array}$ & & & $\begin{array}{l}0.032 \\
(1.932 *)\end{array}$ & \\
\hline $\begin{array}{l}\text { Unexpected Total Real Earnings Management } \\
\text { in Quarters }(-4,-1)\end{array}$ & & & $\begin{array}{l}0.035 \\
(2.013 * *)\end{array}$ & & & $\begin{array}{l}0.032 \\
(1.863 *)\end{array}$ \\
\hline $\operatorname{Ln}($ Deal Value $)$ & $\begin{array}{l}-0.055 \\
(-2.960 * * *)\end{array}$ & $\begin{array}{l}-0.057 \\
(-3.272 * * *)\end{array}$ & $\begin{array}{l}-0.057 \\
(-3.262 * * *)\end{array}$ & $\begin{array}{l}-0.060 \\
\left(-3.276^{* * *}\right)\end{array}$ & $\begin{array}{l}-0.063 \\
(-3.695 * * *)\end{array}$ & $\begin{array}{l}-0.063 \\
(-3.684 * * *)\end{array}$ \\
\hline Partial Acquisitions & $\begin{array}{l}-0.022 \\
(-1.762 *)\end{array}$ & $\begin{array}{l}-0.019 \\
(-1.664 *)\end{array}$ & $\begin{array}{l}-0.019 \\
\left(-1.677^{*}\right)\end{array}$ & $\begin{array}{l}-0.003 \\
(-0.249)\end{array}$ & $\begin{array}{l}-0.002 \\
(-0.185)\end{array}$ & $\begin{array}{l}-0.002 \\
(-0.213)\end{array}$ \\
\hline Related Target & $\begin{array}{l}0.006 \\
(0.411)\end{array}$ & $\begin{array}{l}0.008 \\
(0.615)\end{array}$ & $\begin{array}{l}0.008 \\
(0.610)\end{array}$ & $\begin{array}{l}0.003 \\
(0.241)\end{array}$ & $\begin{array}{l}0.006 \\
(0.414)\end{array}$ & $\begin{array}{l}0.006 \\
(0.415)\end{array}$ \\
\hline Cash Only & $\begin{array}{l}0.061 \\
(3.749 * * *)\end{array}$ & $\begin{array}{l}0.054 \\
(3.549 * * *)\end{array}$ & $\begin{array}{l}0.054 \\
(3.556 * * *)\end{array}$ & $\begin{array}{l}0.056 \\
(3.438 * * *)\end{array}$ & $\begin{array}{l}0.048 \\
(3.173 * * *)\end{array}$ & $\begin{array}{l}0.048 \\
(3.177 * * *)\end{array}$ \\
\hline Private Targets & $\begin{array}{l}0.085 \\
(4.619 * * *)\end{array}$ & $\begin{array}{l}0.077 \\
(4.438 * * *)\end{array}$ & $\begin{array}{l}0.077 \\
(4.419 * * *)\end{array}$ & $\begin{array}{l}0.095 \\
(5.209 * * *)\end{array}$ & $\begin{array}{l}0.084 \\
(4.895 * * *)\end{array}$ & $\begin{array}{l}0.084 \\
(4.877 * * *)\end{array}$ \\
\hline Cash Only* Private Targets & $\begin{array}{l}0.053 \\
(3.193 * * *)\end{array}$ & $\begin{array}{l}0.046 \\
(2.979 * * *)\end{array}$ & $\begin{array}{l}0.046 \\
(2.970 * * *)\end{array}$ & $\begin{array}{l}0.059 \\
(3.506 * * *)\end{array}$ & $\begin{array}{l}0.051 \\
\left(3.216^{* * *}\right)\end{array}$ & $\begin{array}{l}0.050 \\
(3.207 * * *)\end{array}$ \\
\hline Industry-Adjusted Operating Cash & 0.017 & 0.018 & 0.018 & 0.040 & 0.041 & 0.040 \\
\hline Flows/Assets & $(0.355)$ & $(0.386)$ & $(0.382)$ & $(0.829)$ & $(0.855)$ & $(0.852)$ \\
\hline Industry-Adjusted Market-To-Book & $\begin{array}{l}0.136 \\
\left(1.810^{*}\right)\end{array}$ & $\begin{array}{l}0.135 \\
(1.840 *)\end{array}$ & $\begin{array}{l}0.135 \\
(1.839 *)\end{array}$ & $\begin{array}{l}0.150 \\
\left(2.071^{* *}\right)\end{array}$ & $\begin{array}{l}0.148 \\
\left(2.105^{* *}\right)\end{array}$ & $\begin{array}{l}0.148 \\
(2.104 * *)\end{array}$ \\
\hline Industry-Adjusted Debt Ratio & $\begin{array}{l}-0.063 \\
\left(-3.886^{* * *}\right)\end{array}$ & $\begin{array}{l}-0.054 \\
\left(-3.543^{* * *}\right)\end{array}$ & $\begin{array}{l}-0.055 \\
\left(-3.586^{* * *}\right)\end{array}$ & $\begin{array}{l}-0.078 \\
\left(-4.878^{* * *}\right)\end{array}$ & $\begin{array}{l}-0.070 \\
\left(-4.638^{* * *}\right)\end{array}$ & $\begin{array}{l}-0.070 \\
(-4.654 * * *)\end{array}$ \\
\hline F-stat & $3.93 * * *$ & $3.73 * * *$ & $3.72 * * *$ & $3.86^{* * *}$ & $3.61 * * *$ & $3.60 * * *$ \\
\hline Adj. R-squared & 0.0356 & 0.0354 & 0.0352 & 0.0418 & 0.0408 & 0.0407 \\
\hline Year fixed effects & Yes & Yes & Yes & Yes & Yes & Yes \\
\hline Firm clustered standard errors & Yes & Yes & Yes & Yes & Yes & Yes \\
\hline Observations & 5,222 & 5,772 & 5,773 & 5,222 & 5,772 & 5,773 \\
\hline
\end{tabular}

The table reports the cross-sectional analyses of acquirer's average abnormal returns (AARs) calculated over the quarter preceding announcement quarter. AAR is the average of the difference between the daily return of the bidder firm and the predicted daily return of the firm from either the market model or the Fama-French 3-factor model, alternatively. We estimate the parameters of the models using daily returns in the $(-8,-5)$ quarters window, with day 0 representing the quarter of the M\&A announcement. AAR represents the average of daily abnormal returns over the $(-4,-1)$ quarters preceding the quarter of the M\&A announcement. Industry-adjusted implies that the median industry score for the quarter is subtracted from the firm's score. The t-statistics are given in parentheses and are adjusted for heteroskedasticity and for clustering by firm. ***,**, and* stand for statistical significance at the $1 \%, 5 \%$, and $10 \%$ level, respectively. 
Table 9 - Cross-Sectional Analyses of Bidders' AARs by Subsamples

\begin{tabular}{|c|c|c|c|c|}
\hline \multirow{2}{*}{ Variables } & \multicolumn{2}{|c|}{ Panel A - Cash only } & \multicolumn{2}{|c|}{ Panel B - Stock Only \& Stock-Cash } \\
\hline & Model 1 & Model 2 & Model 3 & Model 4 \\
\hline Intercept & $\begin{array}{l}-0.028 \\
(-1.447)\end{array}$ & $\begin{array}{l}-0.040 \\
(-2.138 * *)\end{array}$ & $\begin{array}{l}-0.026 \\
(-1.011)\end{array}$ & $\begin{array}{l}-0.043 \\
(-1.983 * *)\end{array}$ \\
\hline Average Discretionary Accruals in Quarters $(-4,-1)$ & $\begin{array}{l}0.015 \\
(0.567)\end{array}$ & & $\begin{array}{l}-0.014 \\
(-0.782)\end{array}$ & \\
\hline Total Real Earnings Management in Quarters $(-4,-1)$ & & $\begin{array}{l}0.008 \\
(0.273)\end{array}$ & & $\begin{array}{l}0.033 \\
(1.761 *)\end{array}$ \\
\hline Ln(Deal Value) & $\begin{array}{l}-0.008 \\
(-0.287)\end{array}$ & $\begin{array}{l}-0.014 \\
(-0.505)\end{array}$ & $\begin{array}{l}-0.066 \\
\left(-3.016^{* * *}\right)\end{array}$ & $\begin{array}{l}-0.070 \\
\left(-3.435^{* * *}\right)\end{array}$ \\
\hline Partial Acquisitions & $\begin{array}{l}-0.028 \\
(-1.048)\end{array}$ & $\begin{array}{l}-0.026 \\
(-1.044)\end{array}$ & $\begin{array}{l}0.003 \\
(0.229)\end{array}$ & $\begin{array}{l}0.004 \\
(0.337)\end{array}$ \\
\hline Related Target & $\begin{array}{l}0.032 \\
(1.152)\end{array}$ & $\begin{array}{l}0.036 \\
(1.350)\end{array}$ & $\begin{array}{l}-0.004 \\
(-0.270)\end{array}$ & $\begin{array}{l}-0.003 \\
(-0.177)\end{array}$ \\
\hline Private Targets & $\begin{array}{l}0.015 \\
(0.519)\end{array}$ & $\begin{array}{l}0.011 \\
(0.376)\end{array}$ & $\begin{array}{l}0.086 \\
(5.007 * * *)\end{array}$ & $\begin{array}{l}0.075 \\
(4.642 * * *)\end{array}$ \\
\hline Industry-Adjusted Operating Cash Flows/Assets & $\begin{array}{l}-0.018 \\
(-0.633)\end{array}$ & $\begin{array}{l}-0.014 \\
(-0.487)\end{array}$ & $\begin{array}{l}0.047 \\
(0.846)\end{array}$ & $\begin{array}{l}0.047 \\
(0.859)\end{array}$ \\
\hline Industry-Adjusted Market-To-Book & $\begin{array}{l}0.035 \\
(2.458 * *)\end{array}$ & $\begin{array}{l}0.073 \\
(3.320 * * *)\end{array}$ & $\begin{array}{l}0.161 \\
\left(2.075^{* *}\right)\end{array}$ & $\begin{array}{l}0.160 \\
(2.091 * *)\end{array}$ \\
\hline Industry-Adjusted Debt Ratio & $\begin{array}{l}-0.012 \\
(-0.381)\end{array}$ & $\begin{array}{l}-0.014 \\
(-0.454)\end{array}$ & $\begin{array}{l}-0.089 \\
(-4.857 * * *)\end{array}$ & $\begin{array}{l}-0.079 \\
(-4.569 * * *)\end{array}$ \\
\hline F-stat & $1.59 * * *$ & $1.63 * * *$ & $3.90 * * *$ & $3.64 * * *$ \\
\hline Adj. R-squared & 0.0113 & 0.0119 & 0.0495 & 0.0477 \\
\hline Year fixed effects & Yes & Yes & Yes & Yes \\
\hline Firm clustered standard errors & Yes & Yes & Yes & Yes \\
\hline Observations & 1,411 & 1,522 & 3,811 & 4,250 \\
\hline
\end{tabular}

The table reports the cross-sectional analyses of acquirer's average abnormal returns (AARs) calculated over the 4 quarters preceding announcement quarter for each subsample. AAR is the average of the difference between the daily return of the bidder firm and the predicted daily return of the firm from the Fama-French 3 -factor model. We estimate the parameters of the model using daily returns in the $(-8,-5)$ quarters window, with day 0 representing the quarter of the M\&A announcement. AAR represents the average of daily abnormal returns over the $(-4,-1)$ quarters preceding the quarter of the M\&A announcement. Industry-adjusted implies that the median industry score for the quarter is subtracted from the firm's score. The t-statistics are given in parentheses and are adjusted for heteroskedasticity and for clustering by firm. $* * *, * *$, and* stand for statistical significance at the $1 \%, 5 \%$, and $10 \%$ level, respectively. 
Table 10 - Univariate Analyses of Bidders' BHARs by Quartiles of Earnings Management Measures

\begin{tabular}{|c|c|c|c|c|c|}
\hline & & & & & 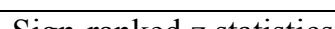 \\
\hline \multirow{3}{*}{$(+1,+12)$ months } & Raw BHR & $7487 \%$ & $1977 \%$ & $1011 * * *$ & $5,05 * * *$ \\
\hline & Market-adjusted BHR & $-2.447 \%$ & $-7.948 \%$ & $-3.60 * * *$ & $-11.37 * * *$ \\
\hline & Match-adjusted BHR & $-1.366 \%$ & $-2.828 \%$ & $-1.30 * * *$ & $-3.03 * * *$ \\
\hline \multirow[t]{3}{*}{$(+1,+24)$ months $)$} & Raw BHR & $14.528 \%$ & $4.350 \%$ & $14.28 * * *$ & $7.80 * * *$ \\
\hline & Market-adjusted BHR & $-5.740 \%$ & $-14.418 \%$ & $-6.04 * * *$ & $-14.17 * * *$ \\
\hline & Match-adjusted BHR & $-3.605 \%$ & $-4.615 \%$ & $-2.42 * * *$ & $-3.74 * * *$ \\
\hline \multirow[t]{3}{*}{$(+1,+36)$ months } & Raw BHR & $25.298 \%$ & $7.485 \%$ & $19.34 * * *$ & $12.02 * * *$ \\
\hline & Market-adjusted BHR & $-5.351 \%$ & $-19.220 \%$ & $-4.39 * * *$ & $-14.27 * * *$ \\
\hline & Match-adjusted BHR & $-4.202 \%$ & $-9.673 \%$ & $-2.26 * * *$ & $-5.37 * * *$ \\
\hline
\end{tabular}

Panel B - By quartiles of earnings management measures - Whole Sample

Earnings management measures

\begin{tabular}{lllllllll}
\hline Discretionary & $(+1,+12)$ & $4.076 \%$ & $-3.873 \%$ & $-3.664 \%$ & $-2.347 \%$ & $-6.422 \%$ & $-1.87^{*}$ & -1.04 \\
accruals & $(+1,+24)$ & $6.228 \%$ & $-7.541 \%$ & $-5.791 \%$ & $-8.988 \%$ & $-15.216 \%$ & $-3.08^{* * *}$ & $-2.03^{* *}$ \\
& $(+1,+36)$ & $8.713 \%$ & $-11.995 \%$ & $-4.148 \%$ & $-9.046 \%$ & $-17.759 \%$ & $-2.94 * * *$ & $-1.75^{*}$ \\
Total real earnings & $(+1,+12)$ & $3.070 \%$ & $2.592 \%$ & $-5.461 \%$ & $-5.620 \%$ & $-8.690 \%$ & $-2.15^{* *}$ & $-1.67^{*}$ \\
management & $(+1,+24)$ & $-0.455 \%$ & $-1.746 \%$ & $-3.591 \%$ & $-8.753 \%$ & $-8.298 \%$ & $-2.28^{* *}$ & $-2.38^{* *}$ \\
& $(+1,+36)$ & $0.911 \%$ & $-2.948 \%$ & $-4.521 \%$ & $-10.586 \%$ & $-11.497 \%$ & $-2.68^{* * *}$ & $-2.55^{* * *}$ \\
Unexpected total & $(+1,+12)$ & $2.662 \%$ & $2.529 \%$ & $-5.334 \%$ & $-5.264 \%$ & $-7.926 \%$ & $-2.04 * *$ & $-1.71^{* *}$ \\
real earnings & $(+1,+24)$ & $-0.057 \%$ & $-1.665 \%$ & $-4.007 \%$ & $-8.774 \%$ & $-8.717 \%$ & $-2.34 * *$ & $-2.29 * *$ \\
management & $(+1,+36)$ & $1.660 \%$ & $-2.914 \%$ & $-6.659 \%$ & $-9.138 \%$ & $-10.798 \%$ & $-2.87^{* *}$ & $-2.39^{* *}$ \\
\hline
\end{tabular}

Panel C-By quartiles of earnings management measures - Cash-Only Subsample Earnings management Windows Quartile 1 Quartile 2 Quartile 3 Quartile 4 (4) minus (1) t-stat

Wilcoxon measures

\begin{tabular}{lllllllll}
\hline Discretionary & $(+1,+12)$ & $5.506 \%$ & $-0.991 \%$ & $-2.199 \%$ & $-2.162 \%$ & $-7.668 \%$ & -1.29 & -0.92 \\
accruals & $(+1,+24)$ & $12.748 \%$ & $-2.926 \%$ & $-2.616 \%$ & $-8.223 \%$ & $-20.970 \%$ & $-2.40^{* *}$ & $-2.32^{* *}$ \\
& $(+1,+36)$ & $20.881 \%$ & $-6.085 \%$ & $-1.901 \%$ & $-2.847 \%$ & $-23.728 \%$ & $-2.03^{* *}$ & $-2.02^{* *}$ \\
Total real earnings & $(+1,+12)$ & $7.215 \%$ & $3.589 \%$ & $-4.497 \%$ & $-2.487 \%$ & $-9.703 \%$ & $-1.67^{*}$ & $-1.82^{*}$ \\
management & $(+1,+24)$ & $7.409 \%$ & $0.837 \%$ & $-1.644 \%$ & $-3.420 \%$ & $-10.828 \%$ & $-2.27^{* *}$ & $-2.38^{* *}$ \\
& $(+1,+36)$ & $5.973 \%$ & $0.697 \%$ & $1.753 \%$ & $-0.227 \%$ & $-6.200 \%$ & $-2.04^{* *}$ & $-2.45^{* *}$ \\
Unexpected total & $(+1,+12)$ & $7.781 \%$ & $2.859 \%$ & $-4.201 \%$ & $-2.611 \%$ & $-10.392 \%$ & $-1.91^{*}$ & $-1.76^{*}$ \\
real earnings & $(+1,+24)$ & $9.244 \%$ & $0.007 \%$ & $-1.477 \%$ & $-4.089 \%$ & $-13.333 \%$ & $-2.13^{* *}$ & $-2.18^{* *}$ \\
management & $(+1,+36)$ & $9.463 \%$ & $0.098 \%$ & $-1.167 \%$ & $1.017 \%$ & $-8.446 \%$ & $-2.21^{* *}$ & $-2.19^{* *}$ \\
\hline
\end{tabular}

\section{Panel D - By quartiles of earnings management measures - Stock-Only and Stock-Cash Subsamples}

Earnings management measures

Discretionary

accruals

Total real earnings

management

Unexpected total

real earnings

management
Windows Quartile 1 Quartile 2 Quartile 3 Quartile 4

(4) minus (1)

$(+1,+24)$

$(+1,+36)$

$(+1,+12)$

$(+1,+24)$

$(+1,+36)$

$(+1,+12)$

$(+1,+24)$

$(+1,+36)$

\section{$3.584 \%$}

$3.988 \%$

$4.544 \%$

$2.162 \%$

$-2.178 \%$

$-0.195 \%$

$1.526 \%$

$-2.123 \%$

$-0.069 \%$

\begin{tabular}{ll}
$-5.252 \%$ & $-4.307 \%$ \\
$-9.748 \%$ & $-7.183 \%$ \\
$-14.822 \%$ & $-5.133 \%$ \\
$2.213 \%$ & $-6.131 \%$ \\
$-2.728 \%$ & $-4.477 \%$ \\
$-4.333 \%$ & $-7.376 \%$ \\
$2.404 \%$ & $-5.848 \%$ \\
$-2.297 \%$ & $-5.153 \%$ \\
$-4.052 \%$ & $-9.148 \%$ \\
\hline
\end{tabular}

$-7.183 \%$

$-2.399 \%$

$-9.204 \%$

$-10.791 \%$

$-6.843 \%$

$-11.231 \%$

$-15.401 \%$

$-6.497 \%$

$-10.952 \%$

$-13.860 \%$

$-5.983 \%$

$-13.191 \%$

$-15.335 \%$

$-9.005 \%$

$-9.053 \%$

$-15.205 \%$

$-8.023 \%$

$-8.829 \%$

$-13.791 \%$ t-stat

Wilcoxon

stat

\begin{tabular}{ll}
-1.45 & $-1.67 *$ \\
$-2.24 * *$ & $-2.23^{* *}$ \\
$-2.16^{* *}$ & $-2.23^{* *}$ \\
$-2.01^{* *}$ & $-1.78^{*}$ \\
$-2.10^{* *}$ & $-2.24 * *$ \\
$-2.63^{* * *}$ & $-2.42^{* *}$ \\
$-2.03^{* *}$ & $-1.96^{* *}$ \\
$-2.23^{* *}$ & $-2.23^{* *}$ \\
$-2.61^{* *}$ & $-2.56^{* * *}$ \\
\hline
\end{tabular}

The table reports mean values of bidders' long-run stock performance in the 12-, 24- and 36 months post-announcement. Buy and hold abnormal returns (BHARs) is measured as the difference between the buy-and-hold return of the bidding firm and a matching firm's buy-and-hold return. A matched firm is a non-bidder that is in the same size quartile and is closest in the market-to-book ratio as the bidder firm in the quarter preceding the M\&A announcement date. We break the sample into quartiles based on the bidders' earnings management scores in the four quarters leading up to the M\&A announcement. Quartile 4 represents firms with the highest scores of earnings manipulations and quartile 1 representing firms with the lowest scores. ${ }^{* * *},{ }^{* *}$, and* stand for statistical significance at the $1 \%, 5 \%$, and $10 \%$ level, respectively. 
Table 11 - Cross-Sectional Analyses of Bidders' BHARs by Subsamples

\begin{tabular}{|c|c|c|c|c|c|c|c|}
\hline \multirow[b]{2}{*}{ Variables } & \multicolumn{3}{|c|}{ Panel A-Whole Sample } & \multicolumn{2}{|c|}{ Panel B - Cash only } & \multicolumn{2}{|c|}{$\begin{array}{l}\text { Panel C - Stock Only \& } \\
\text { Stock-Cash }\end{array}$} \\
\hline & Model 1 & Model 2 & Model 3 & Model 5 & Model 6 & Model 7 & Model 8 \\
\hline Constant & $\begin{array}{l}-0.032 \\
(-0.250)\end{array}$ & $\begin{array}{l}0.171 \\
(1.123)\end{array}$ & $\begin{array}{l}0.171 \\
(1.127)\end{array}$ & $\begin{array}{l}0.123 \\
(1.060)\end{array}$ & $\begin{array}{l}0.464 \\
(4.805 * * *)\end{array}$ & $\begin{array}{l}-0.150 \\
(-0.659)\end{array}$ & $\begin{array}{l}0.139 \\
(0.834)\end{array}$ \\
\hline Matched-Adjusted Discretionary Accruals In & 0.009 & & & -0.087 & & -0.006 & \\
\hline Quarters $(-4,-1)$ & $(0.346)$ & & & $(-2.075 * *)$ & & $(-0.197)$ & \\
\hline Matched-Adjusted Discretionary Accruals In & -0.043 & & & 0.072 & & -0.027 & \\
\hline Matched-Adjusted Total Real Activities & & -0.036 & & & & & \\
\hline Manipulation In Quarters $(-4,-1)$ & & $(-1.839 *)$ & & & & & \\
\hline Matched-Adjusted Total Real Activities & & 0.025 & & & & & \\
\hline Manipulation In Quarters $(+1,+4)$ & & $(1.271)$ & & & & & \\
\hline Matched-Adjusted Unexpected Total Real & & & -0.047 & & -0.091 & & -0.022 \\
\hline Activities Manipulation In Quarters $(-4,-1)$ & & & $(-1.660 *)$ & & $(-2.974 * * *)$ & & $(-1.960 * *)$ \\
\hline Matched-Adjusted Unexpected Total Real & & & 0.032 & & 0.063 & & 0.019 \\
\hline \multirow[t]{2}{*}{ Ln(Deal Value) } & 0.003 & 0.006 & 0.006 & 0.009 & 0.011 & 0.001 & 0.003 \\
\hline & $(0.407)$ & $(0.801)$ & $(0.799)$ & $(0.743)$ & $(0.958)$ & $(0.143)$ & $(0.400)$ \\
\hline \multirow[t]{2}{*}{ Partial Acquisitions } & -0.024 & -0.025 & -0.024 & -0.061 & -0.061 & -0.011 & -0.014 \\
\hline & $(-0.691)$ & $(-0.761)$ & $(-0.729)$ & $(-1.202)$ & $(-1.235)$ & $(-0.242)$ & $(-0.337)$ \\
\hline \multirow[t]{2}{*}{ High-Tech Target } & 0.034 & 0.037 & 0.037 & -0.050 & -0.044 & 0.059 & 0.062 \\
\hline & $(2.384 * * *)$ & $(2.534 * * *)$ & $(2.542 * * *)$ & $(-1.463)$ & $(-1.317)$ & $(1.892 *)$ & $(2.050 * *)$ \\
\hline \multirow[t]{2}{*}{ Related Target } & 0.017 & 0.018 & 0.018 & 0.019 & 0.024 & 0.021 & 0.020 \\
\hline & $(0.719)$ & $(0.786)$ & $(0.791)$ & $(0.526)$ & $(0.697)$ & $(0.688)$ & $(0.693)$ \\
\hline \multirow[t]{2}{*}{ Cash Only } & 0.022 & 0.024 & 0.024 & & & & \\
\hline & $\left(1.675^{*}\right)$ & $\left(1.791^{*}\right)$ & $\left(1.791^{*}\right)$ & & & & \\
\hline \multirow[t]{2}{*}{ Private Targets } & 0.006 & 0.008 & 0.008 & 0.072 & 0.072 & 0.005 & 0.010 \\
\hline & $(2.164 * *)$ & $(2.259 * *)$ & $(2.253 * *)$ & $\left(1.907^{*}\right)$ & $\left(1.938^{*}\right)$ & $(2.137 * *)$ & $(2.296 * *)$ \\
\hline \multirow[t]{2}{*}{ Cash Only* Private Targets } & 0.041 & 0.037 & 0.037 & & & & \\
\hline & $\left(1.919^{*}\right)$ & $(1.859 *)$ & $(1.859 *)$ & & & & \\
\hline Matched-Adjusted Operating Cash & 3.074 & 3.065 & 3.067 & 3.772 & 3.763 & 2.955 & 2.965 \\
\hline Matched-Adjusted Debt Ratio & $(0.147)$ & $(0.093)$ & $(0.093)$ & $(-0.012)$ & $(-0.008)$ & $(0.128)$ & $(0.062)$ \\
\hline F-statistics & $5.70 * * *$ & $5.59 * * *$ & $5.55 * * *$ & $4.07 * * *$ & $3.95 * * *$ & $4.94 * * *$ & $4.87 * * *$ \\
\hline Adj. R-squared & 0.088 & 0.089 & 0.089 & 0.113 & 0.120 & 0.091 & 0.091 \\
\hline Year fixed effects & Yes & Yes & Yes & Yes & Yes & Yes & Yes \\
\hline Clustered standard errors by firms & Yes & Yes & Yes & Yes & Yes & Yes & Yes \\
\hline Observations & 4,303 & 4,695 & 4,696 & 1,190 & 1,266 & 3,113 & 3,429 \\
\hline
\end{tabular}




\section{Review of Accounting and Finance}

The table reports coefficient estimates of acquirer buy and hold abnormal returns (BHARs), which are calculated over the 12 months following the M\&A announcement. Buy and hold abnormal returns (BHARs) is measured as the difference between the buy-and-hold return of the bidding firm and a matching firm's buy-and-hold return. A matched firm is a non-bidder that is in the same size quartile and is closest in the market-to-book ratio as the bidder firm in the quarter preceding the M\&A announcement date. The t-statistics are given in parentheses and are adjusted for heteroskedasticity and clustering by firm. All regressions include year dummies. ${ }^{* * *},{ }^{* *}$, and ${ }^{*}$ stand for statistical significance at the $1 \%$, $5 \%$, and $10 \%$ level, respectively. 


\section{Figure 1 - Trend in Earnings Management by Bidders around Merger Announcements for the Whole Sample}

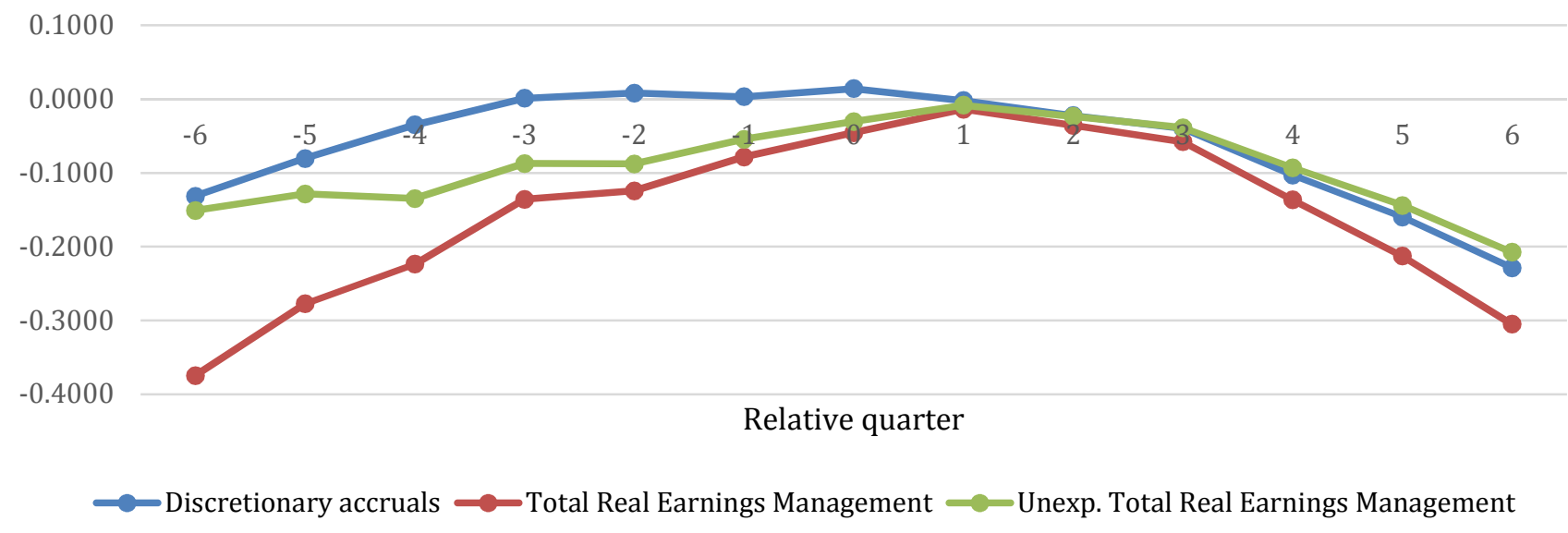

Figure 2 - Trend in Earnings Management by Bidders around Merger Announcements for the Cash-Only Subsample

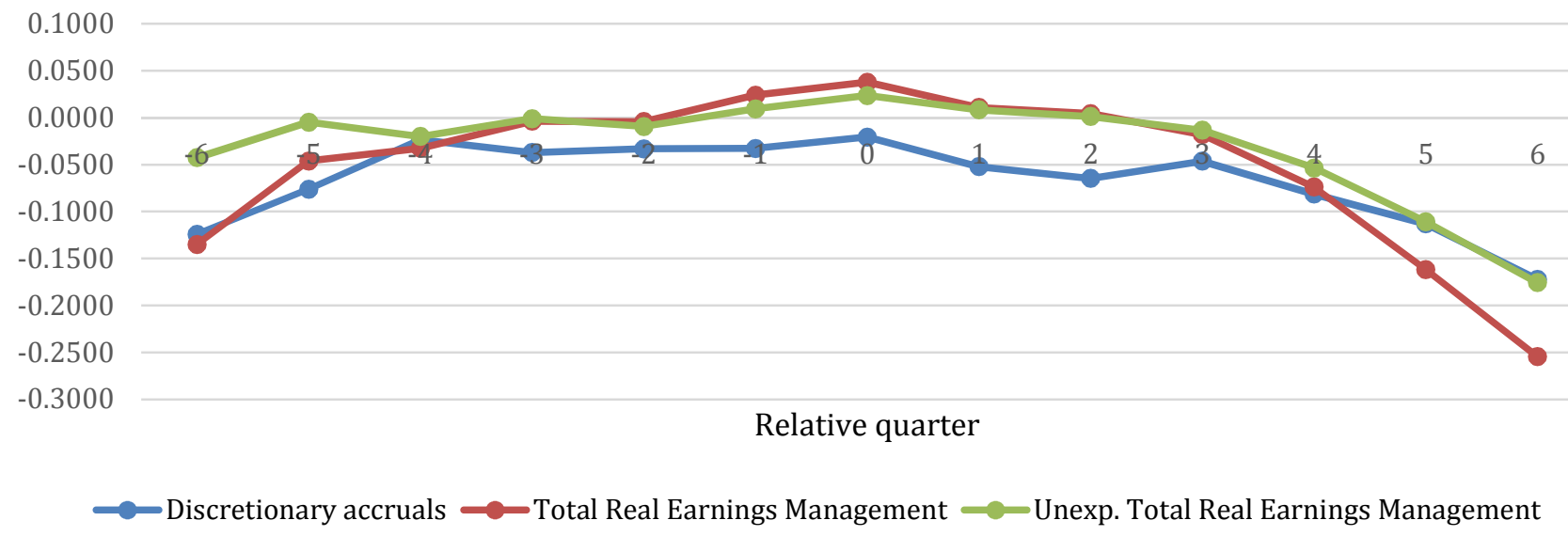

Figure 3 - Trend in Earnings Management by Bidders around Merger Announcements for the Stock-Only \& Stock-Cash Subsample

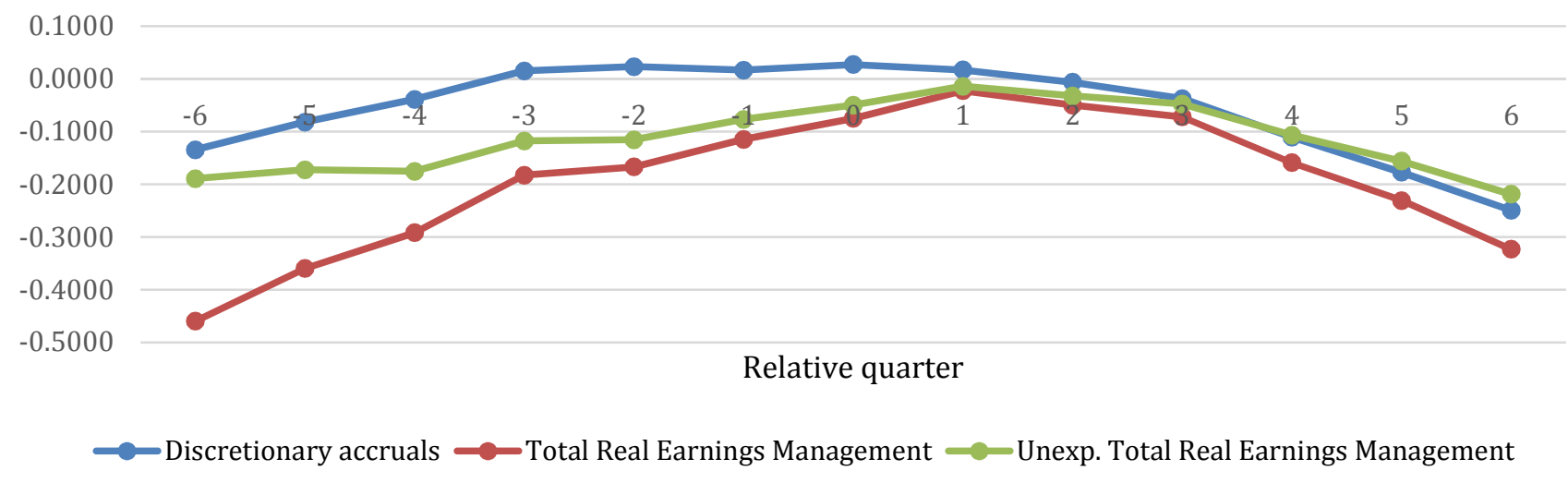




\section{Figure 4 - Trend in Earnings Management by Bidders around Merger Announcements for Public Target Subsample}

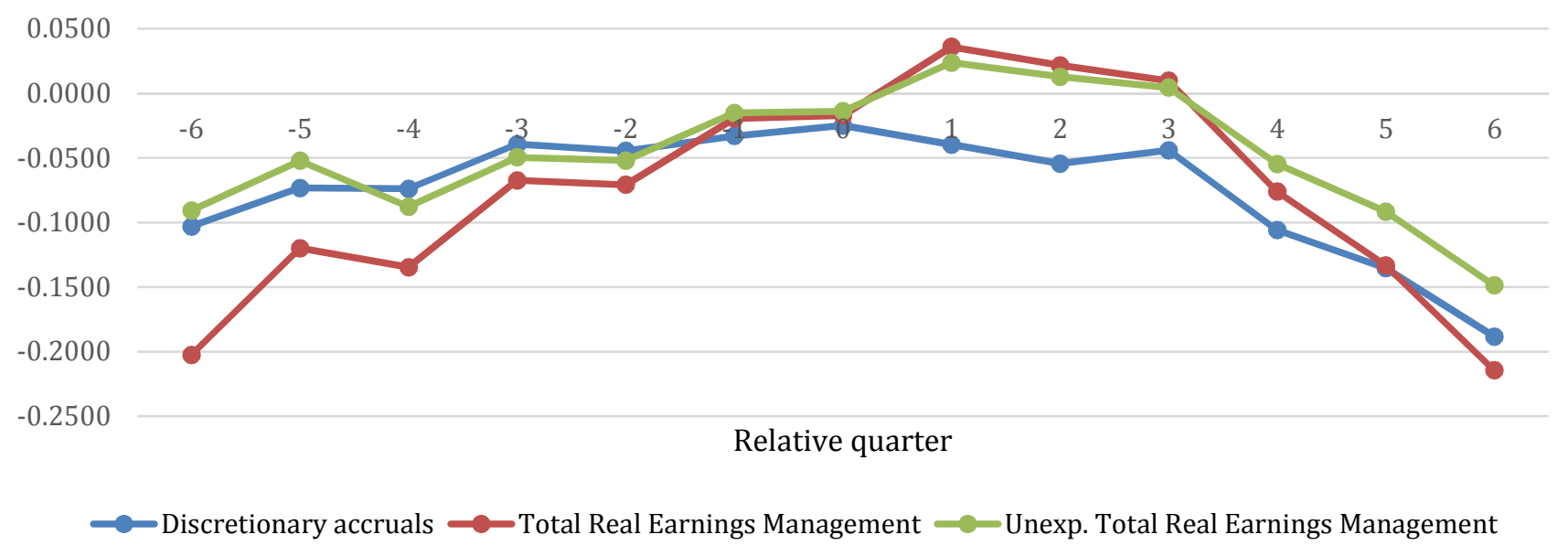

\section{Figure 5 - Trend in Earnings Management by Bidders around} Merger Announcements for Private Target Subsample

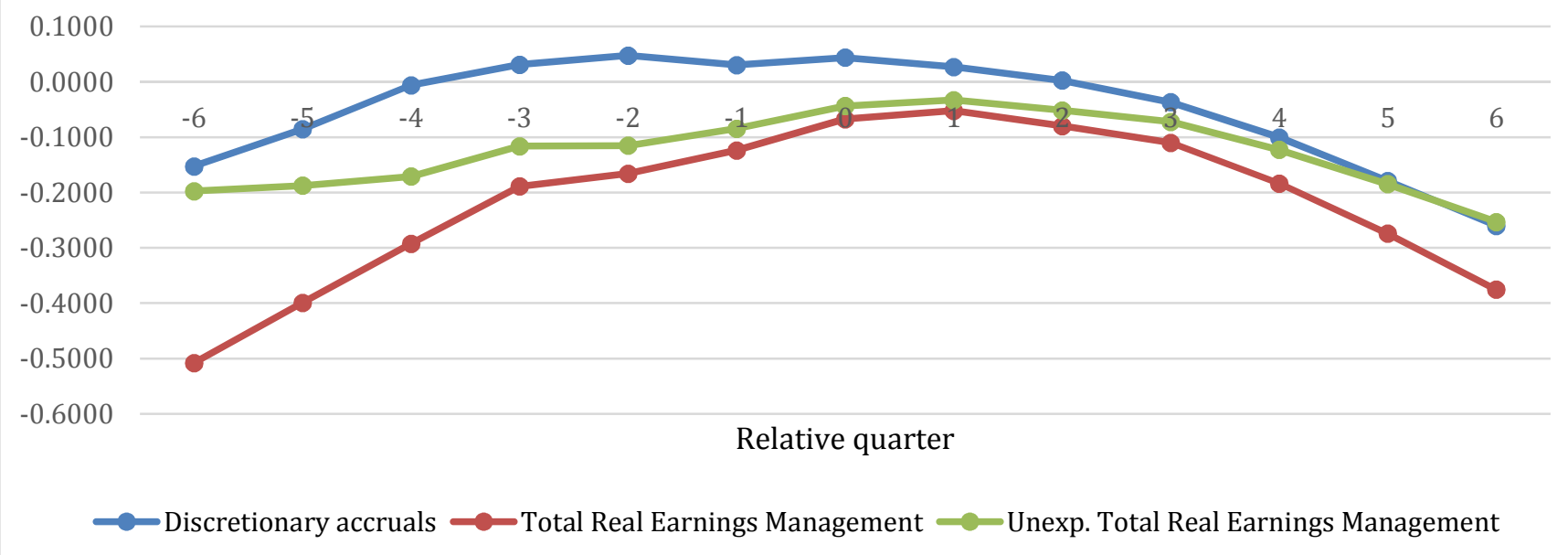

